\title{
Demutualisation, Control and Efficiency in the U.S. Life Insurance Industry
}

\author{
Xiaoying Xie ${ }^{\mathrm{a}}$, Weili Lu ${ }^{\mathrm{a}}$, Joseph Reising ${ }^{\mathrm{b}}$ and Mark Hoven Stohs ${ }^{\mathrm{a}}$ \\ a Department of Finance, Mihaylo College of Business and Economics, California State University, \\ Fullerton, CA 92834, U.S.A. \\ E-mails: xxie@fullerton.edu; wlu@fullerton.edu; mstohs@fullerton.edu \\ ${ }^{\mathrm{b}}$ Department of Finance, College of Business, Minnesota State University-Mankato, Mankato, MN 56001, \\ U.S.A. \\ E-mail: joseph.reising@mnsu.edu
}

This paper examines the role of corporate governance in the demutualisation wave in the U.S. life insurance industry during the 1990s and 2000s. The efficiency hypothesis suggests a firm should experience improved performance after demutualisation and managers should only gain from superior performance. Alternately, the managerial welfare hypothesis proposes that executives gain independence of company performance. This research suggests that demutualisation is value-enhancing for firms converting through initial public offerings (IPOs), but value-neutral for firms that convert but stay private. Firms converting into public companies experience increased CEO turnover that leads to efficiency improvement. CEOs of these firms receive higher compensation after demutualisation, but most of the gain is due to a jump in incentive compensation. Firms converting but staying private do not have a similar significant increase in CEO compensation. Overall, our results provide evidence that value-enhancement, not private managerial welfare, motivates demutualisation.

The Geneva Papers (2011) 36, 197-225. doi:10.1057/gpp.2011.6;

published online 2 March 2011

Keywords: demutualisation; life insurance; data envelopment analysis (DEA); CEO turnover; CEO compensation

\section{Introduction}

During the 1990s and early 2000s, the proportion of life insurance assets under management by mutual firms in the U.S. dropped from over 40 per cent to less than 15 per cent. The major cause was a wave of demutualisation that significantly decreased the number of mutual companies in the industry. ${ }^{1}$ Literature on organisational form diverges. Spiller ${ }^{2}$ and Frech $^{3}$ found that stock structure is more efficient in life and health insurance firms, whereas Fama and Jensen ${ }^{4}$ and Mayers and Smith ${ }^{5}$ argued

\footnotetext{
${ }^{1}$ For example, there were fewer than 70 mutual firms still in existence in the U.S. in 2003, while about 110 mutual firms operated in the market in 1993. This statistic comes from the National Association of Insurance Commissioners (NAIC) data for the U.S. life-health insurance industry.

2 Spiller (1972).

${ }^{3}$ Frech (1980).

${ }^{4}$ Fama and Jensen (1983a).

${ }^{5}$ Mayers and Smith (1981, 1986, 1988, 1994).
} 
that the mutual structure includes certain benefits and efficiencies not accessible to alternate structures. The latter suggests an equilibrium in which mutual firms coexist with stock firms. What factors, then, drove the wave of demutualisation in the 1990s? We argue that insight can be gained through an examination of the determinants and outcomes of that demutualisation wave, and, in particular, the managerial motivation behind it.

Standard explanations of choices between organisational forms typically involve incentives to improve firm efficiency. The significant influence managers have on the process of organisational form change, however, also making it possible for managers to engage in transactions to maximise their own welfare at the expense of other parties. Consequently, an important issue for the study of demutualisation is the identification of its main beneficiaries, whether they are the firm entities (represented by the existing policy-holders and potential stockholders after demutualisation) or management. Enhanced firm performance would suggest that demutualisation is predominantly driven by the desire for enhanced efficiency and profitability, in addition to a willingness to accept greater contracting costs to manage owner-policy-holder agency issues. This is the efficiency (value-enhancement) hypothesis. ${ }^{6}$

Alternatively, if benefits tend to accrue at the management level rather than at the firm level, then demutualisation is more likely driven by the private interests of the management, as suggested by the managerial welfare hypothesis. ${ }^{7}$ If the transaction is designed to benefit managers, then it is unlikely that the efficiency of firms would improve after demutualisation. Rather, one expects to see managers attempt to benefit by expropriating the wealth of the company and/or entrenching their positions to reap the rewards of such expropriation over an extended period of time. That acquisition of private benefits at the expense of the firm would tend to decrease the firm's efficiency.

This study employs empirical data to investigate the two hypotheses about the motivation for demutualisation for firms in the U.S. life insurance industry during the period of 1993-2003. Our major contribution to the literature is a direct test of the managerial welfare hypothesis. Previous studies, such as Viswanathan and Cummins, ${ }^{8}$ examined the operational characteristics associated with the demutualisation decision but did not assess the role of corporate control. Recent literature, such as Lai et al., ${ }^{9}$ focused on the stock performance of demutualisation and did not address the management compensation, which some have argued motivates the transactions. Other studies encountered data restrictions, resulting in limited or mixed evidence about the efficiency hypothesis and the managerial welfare hypothesis. For example, McNamara and Rhee ${ }^{10}$ examined management turnover for life insurance firms, and Cagle et al., ${ }^{11}$ examined turnover for property and casualty firms. Both papers report greater turnover after demutualisation but do not connect the turnover to firm or managerial performance. In fact, Cagle et al., ${ }^{11}$ admitted that the results of manager

\footnotetext{
${ }^{6}$ Mayers and Smith (2004), Viswanathan and Cummins (2003).

${ }^{7}$ Mayers and Smith (1986), McNamara and Rhee (1992), Cagle et al. (1996), Carson et al. (1998).

${ }^{8}$ Viswanathan and Cummins (2003).

${ }^{9}$ Lai et al. (2008).

${ }^{10}$ McNamara and Rhee (1992).

11 Cagle et al. (1996).
} 
turnover are not consistent with profitability measures. These papers in general did not examine managerial characteristics as important determinants of demutualisation decisions or investigate changes in corporate governance structures or CEO compensation resulting from demutualisation.

In this paper, we provide a comprehensive analysis of 37 demutualised firms, compare them to a matching sample of mutual companies, and distinguish initial public offering (IPO) demutualisation from other forms of demutualisation. First, we provide a direct test of the relationship between a firm's demutualisation decision and its financial and managerial characteristics. The latter includes board size and independence, executive compensation and characteristics of CEOs. By comparing converting companies with matching mutual companies, we identify the ex-ante determinants of demutualisation.

Second, we provide comprehensive measures of firm performance, including accounting ratios and frontier efficiency measurements, which enable us to test the efficiency and managerial welfare hypotheses more effectively. ${ }^{12} \mathrm{We}$ employ frontier efficiency measures because this method is based on classic microeconomic theory and accounts for the multidimensionality of a firm's production process. Frontier efficiency is a good proxy for the effectiveness of management. ${ }^{13} \mathrm{We}$ measure the firms' cost and technical efficiency by using data envelopment analysis (DEA) and test whether converting firms experience post-demutualisation efficiency improvement.

Third, we directly test the managerial welfare hypothesis by analysing the effects of demutualisation on the managerial structure (board size, percentage of independent directors, and CEO turnover) and CEO compensation (with and without stock options), and then analyse whether CEO turnover after demutualisation enhances firms' efficiency.

The remainder of the paper is organised as follows. The following section develops our hypotheses. The subsequent section describes the data and methodology. The next following section presents the results of the ex-ante determinants of demutualisation. The section after that presents the effects of demutualisation on firm efficiency, operating performance and other financials. The penultimate section presents the impact of demutualisation on firms' managerial structure change and CEO compensation, as well as the impact of post-demutualisation CEO replacement on firms' efficiency. The final section concludes the paper.

\section{Hypotheses}

Literature on organisational form and firm ownership structure suggests that a firm is more efficient when its ownership structure fits its business model and offers

\footnotetext{
${ }^{12}$ One paper, by Jeng et al. (2007), studies efficiency pre- and post-demutualisation for the U.S. life insurance industry during 1984-1995 (ten firms), but the paper does not examine the role of corporate governance. Our paper studies a later sample period with a larger sample size and extends the previous analysis by connecting corporate control to firm efficiency.

${ }^{13}$ Cummins and Weiss (2000).
} 
comparative advantages. If the ownership structure is not a good fit, a firm has the incentive to convert to a structure that can improve operation, corporate governance, and flexibility in executive compensation. ${ }^{14}$ Accordingly, if value creation is the primary motivation for demutualisation, a demutualised firm's efficiency or operating performance should generally improve, and the level of executive compensation should be tied to the firm's performance.

An alternative to the efficiency hypothesis is the managerial welfare hypothesis. ${ }^{15}$ This hypothesis suggests that executives of existing mutual firms may seek demutualisation to pursue private interests, both in the short and long term, at the expense of policy-holders. In the short term, managers can "take the money and run" by reaping gains from the demutualisation and then leaving the firm. In the long term, managers can lock in favourable compensation packages regardless (and even at the expense) of firm performance. If the short-term private benefit of the management is the dominant motivation for demutualisation, we would expect to see a combination of firm performance decline and, potentially, a sharp rise in executive compensation. That compensation would tend to be independent of performance, since the value of contingent compensation would be hurt by unfavourable performance. If executives generally aim to entrench themselves for long-term private benefits, we should also observe a decline in CEO turnover after demutualisation, without a concomitant improvement in firm performance.

\section{Company characteristics and demutualisation}

The literature provides a wealth of company characteristics that are potentially relevant to the demutualisation decision. These include access to capital and growth opportunities, ${ }^{16}$ mitigating the costs of free cash flow, ${ }^{17}$ or seeking diversification opportunities. $^{18}$

\section{Access to capital, growth and managerial discretion}

Mutual firms generally face higher costs in raising new capital than stock insurers do, which tends to cause mutual insurers to maintain a higher ex-ante target surplusto-asset ratio than stock insurers. ${ }^{19}$ Converting to the stock form allows mutuals to gain access to capital markets. Mutual firms may need further access to capital in the following situations: (1) their current surplus level is lower compared to their mutual peers, and thus may well need additional capital to support existing operations or fund positive net present value projects; (2) their surplus level is high relative to mutual peers, but further access to capital markets (at a lower cost) is still beneficial "to undertake profitable projects (such as expansion into new product and geographic

\footnotetext{
${ }^{14}$ Mayers and Smith (1988, 1994, 2004), Pottier and Sommer (1997), Lamm-Tennant and Starks (1993).

${ }^{15}$ See Mayers and Smith (2004), McNamara and Rhee (1992), etc.

${ }^{16}$ Fitzgerald (1973, 1990), Butler et al. (2000), Viswanathan and Cummins (2003), Remmers (2003), Mayers and Smith (2002).

${ }^{17}$ Wells et al. (1995), Cole et al. (1995), Carson et al. (1998).

${ }^{18}$ Fitzgerald (1973), Mayers and Smith (2002).

${ }^{19}$ Harrington and Niehaus (2002).
} 
markets or to acquire another insurer) that are (currently) beyond the mutual insurer's investment opportunity set, ..., i.e., the investment opportunity set will be enlarged;" ${ }^{20}$ or (3) their surplus level is high relative to mutual peers as a reflection of the risk of their policy assets, but access to capital markets would allow the firm an alternate method to fund unexpected losses and therefore, consistent with, ${ }^{19}$ allows the firm to have a lower level of capital than if it were a mutual firm. In the last two cases, it may well be that the high surplus is an imperfect substitute for access to capital markets. In either situation, a demutualisation would be associated with the potential for increased efficiency.

Firms with a higher premium growth rate and that are striving for efficiency may be more likely to convert because increasing the growth rate reduces statutory policyholders' surplus and current net income ${ }^{21}$ and creates a higher demand for equity capital. Mutual firms may also demutualise to seek better growth opportunities in the future, if mutual structure restricts their growth potential due to the higher costs of raising capital. In that case, we would observe a negative relationship between premium growth and demutualisation.

We also expect that firms with a higher percentage of separate account assets are more likely to convert than those with lower or no separate account assets because such firms engage in more complex business activities that require greater managerial discretion. Conversion is more likely both because these firms may find themselves competing with non-mutual firms over the separate accounts and, more subtly, because granting executives the necessary authority to manage the accounts can lead to greater agency costs within the mutual structure.

Firms with a higher percentage of business in group lines (which include group life and group annuity business) are more likely to convert if the firm is attempting to maximise efficiency. The group insurance market is more competitive, and group lines require significantly more managerial discretion than individual lines, since group customers have stronger negotiating power over contracts and are more demanding in terms of service. ${ }^{22}$ Consequently, firms underwriting more group business may require more capital support on top of the greater owner-manager agency costs. Converting from mutual to stock charter is likely to address both problems simultaneously.

Finally, we expect that firms with a higher percentage of reinsurance business would be more likely to convert. Previous studies ${ }^{23}$ suggest that reinsurance demand is greater for firms with higher leverage and riskier business and that the purchase of reinsurance can substitute for capital. Therefore, firms with higher reinsurance usage may indicate that their equity capital is currently constrained.

Free cash flow

Controlling free cash flow may also be a motivation in life insurer demutualisation. A large free cash flow may indicate the firm has been successful at accumulating money

\footnotetext{
${ }^{20}$ Carson et al. (1998).

${ }^{21}$ D'Arcy and Gorvett (2004).

${ }^{22}$ Pottier and Sommer (1997).

${ }^{23}$ For example, Garven and Lamm-Tennant (2003), Cole and McCullough (2006).
} 
and maintaining liquidity, but it also creates an agency problem. The agency problem is particularly serious in mutual firms, due to the limited ability of policy-holders to control the firm. It is expected that firms with a greater level of free cash flow are more likely to demutualise in order to better control the agency costs of equity. Further, if a firm's management team is motivated by efficiency, they would tend to maintain a lower level of free cash flow as a signal of limited agency costs after conversion and achieve improved performance from the more efficient use of the cash flow.

\section{Diversification of business}

Since the mutual structure increases, the cost of monitoring management, mutual firms tend to be more focused on business lines and geographical areas that require less managerial discretion. ${ }^{24}$ If mutual firms engage in diversified businesses or seek to diversify, they may have a greater incentive to convert into stock firms. Accordingly, we hypothesise that mutual firms with greater diversification across business lines and geographical areas are more likely to convert than the more focused firms.

\section{Managerial characteristics and demutualisation}

Corporate governance factors can also affect demutualisation decisions. The literature shows that smaller boards are more efficient at maximising firm values, ${ }^{25}$ and managers' ability to entrench themselves in mutual firms is balanced by the mutuals' greater use of outside directors. ${ }^{26}$ We therefore expect that mutuals with a smaller board and/or higher percentage of outside board directors are more likely to make demutualisation decisions that enhance firm value. In addition, since managerial entrenchment is more difficult with the stock charter than with the mutual charter, under the efficiency hypothesis, we expect a decrease in the percentage of outside directors and an increase in CEO turnover after demutualisation, ${ }^{27}$ as the market for corporate control can act as a substitute for outside director monitoring. Moreover, such changes in corporate governance should not decrease firm efficiency.

As in Mayers and Smith, ${ }^{28}$ characteristics of CEOs, such as their age and tenure, are usually used as indicators of human capital accumulation by executives. We do not have any definitive predictions on CEO tenure and the demutualisation decision. On the one hand, CEOs with more years at their companies may be more familiar with their firms' operation; hence, they may be better able to create value for the firm. Their long tenure may also reflect their strong performance over time. On the other hand, long tenure may indicate that a CEO is more entrenched in the firm or potentially close to retirement, either of which may make the pursuit of private benefits through the demutualisation process more likely. ${ }^{29}$

${ }^{24}$ Mayers and Smith (1988, 1994).

${ }^{25}$ Yermack (1996), Eisenberg et al. (1998).

${ }^{26}$ Mayers et al. (1997).

${ }^{27}$ Mayers et al. (1997), Mayers and Smith (1986), McNamara and Rhee (1992).

${ }^{28}$ Mayers and Smith (1992).

${ }^{29}$ It is arguable, however, that if management has become entrenched, they may find that demutualisation is not preferred, as it may result in more strict market supervision, a more competitive managerial skills 
Aside from tenure, we predict that if the primary motivation of demutualisation is "private" managerial welfare, then the age of the CEO will be positively correlated to the likelihood of demutualisation. Older CEOs are closer to retirement and may therefore choose to demutualise in order to maximise their benefits at the point of transition and then exit the firm; their careers will not be affected much by the performance of the firm after conversion. Younger CEOs, however, have more at stake, as their reputations and careers are embedded in the success of the firm. Their private interests should be more aligned with the interests of the firm. It is also possible, however, that a younger executive may choose to convert, wishing to focus on entrenchment to ensure benefits over a longer period of time. In this case, we should observe a lower turnover rate and higher post-conversion compensation in the long run, along with poor firm performance.

\section{Demutualisation, surplus management and CEO compensation}

According to the managerial welfare hypothesis, the managers of mutual firms (especially top executives such as CEOs) typically can benefit from the demutualisation process through pre-conversion accounting management (of policy-holder surplus $)^{30}$ and the arrangement of post-conversion compensation contracts such as increases in salary or incentive compensation (including stock options, stock appreciation rights and restricted stock). If this argument holds, we should observe a lower surplus over asset ratio right before conversion and a subsequent increase in the ratio shortly after conversion, after controlling for the growth and business scope of firms. In terms of compensation, we would observe a significant increase in total compensation of CEOs, even without improvement in firm performance, especially for CEOs who made the demutualisation decision. This would provide some evidence of "expropriation".

On the other hand, if an increase in incentive compensation follows an increase in firm efficiency, it should be regarded as evidence of the efficiency incentive, rather than the managerial welfare incentive. In this case, demutualisation actually represents a Pareto improvement for both the firm and the management, resulting from better control of owner-executive incentive conflicts in stock firms.

\section{IPO demutualisation vs. non-IPO demutualisation}

A noteworthy phenomenon in the demutualisation wave of the 1990s and early 2000s is that a significant percentage (about one-third) of the firms that chose to demutualise also issued IPOs. ${ }^{31}$ In this study, we perform separate analyses to distinguish between

market, and increased requirements for public revelation of firm-specific information. These combined factors may tend to reduce the value of entrenchment, particularly for IPO demutualisation firms. For non-IPO conversions, entrenchment may be able to continue, but to a lesser extent as compared to the mutual form. An ex post investigation of CEO turnover and compensation will provide further evidence concerning this.

${ }^{30}$ Mayers and Smith (2004).

${ }^{31}$ IPO demutualisation is a type of full demutualisation. The converting mutual declares the total number 
these two demutualisation choices. As going public offers firms greater access to outside capital and subjects the management to more rigorous monitoring from the stockholders, regulators and the human capital market, we may find differing results for firms with IPO demutualisation and without IPOs.

\section{Data and methodology}

\section{Data sources}

This paper focuses on the demutualisation of U.S. life insurers from 1993 to 2003. Demutualisation information comes from the Best's Insurance Reports - Life/Health (2004) list of conversions. We cross-checked the sample with Best's Insurance Reports on individual firms, the annual financial statements filed with National Association of Insurance Commissioners (NAIC), information from company websites, and the list of converting firms in Viswanathan and Cummins ${ }^{8}$ and Erhemjamts. ${ }^{32}$ These sources yielded 37 financially healthy converting life and health companies. ${ }^{33} \mathrm{We}$ also collected information about the type of demutualisation that firms chose such as IPO or non-IPO demutualisation. The information on IPO demutualisation comes from Viswanathan ${ }^{34}$ and SNL Financial - Insurance Industry Vital Statistics. The list of demutualisation firms is reported in Table $2 .{ }^{35}$ In total, we documented 37 demutualisation cases, 13 of which went through the IPO process. ${ }^{36}$ As a result of demutualisation, the asset share of mutual companies dropped sharply from 40.4 per cent in 1993 to 14.5 per cent in 2003, and the premiums share fell from 37.1 per cent to 15.1 per cent (Table 1).

We adopted a widely used matching sample method to study the demutualisation. ${ }^{8}$ First, only firms that remained mutual during the sample period are qualified as matching firms. Then, for each converting firm, we select one matching mutual insurer (due to the small number of operating life insurers over time) from the pool of qualified matching candidates, based on asset size and direct premiums written in year

of shares of common stock and preferred stock that it is authorised to issue. Eligible policy-holders (which are defined in the conversion statute) may exchange their ownership for shares in the newly created stock-holding company, cash and/or policy credits (see Viswanathan, 2006). In our sample, the allocation of shares to policy-holders ranges approximately from 54 to 83 per cent (calculated by shares offered to policy-holders as a percentage of total shares outstanding), with a median value of 75 per cent. The IPO offer price-to-the-book value of equity ranges from 0.60 to 1.08 , with a median value of 0.74 . This data comes from SDC platinum, CRSP, Factiva and Viswanathan (2006).

${ }^{32}$ Erhemjamts (2005).

${ }^{33}$ That is, these were firms with positive assets and net worth, with financial data before the conversion year and ongoing operations for some years later, and that did not covert due to regulatory pressure (Viswanathan and Cummins, 2003).

34 Viswanathan (2006).

${ }^{35}$ The conversion year of a demutualisation firm is defined as the year a company decides to convert. We obtained this information from various resources such as A. M. Best, Factiva, etc. If this year is not accurately available, we instead used the year in which a firm changes from mutual organisational form to stock organisational form in the NAIC database or Best's Insurance Report, whichever makes more sense.

${ }^{36}$ As in Viswanathan and Cummins (2003), the general model of demutualisation in our sample is the lead mutual company of a group that converts. Hence, we perform all our analysis at the company level. 
Table 1 Summary of the U.S. life-health insurance industry by organisational form

\begin{tabular}{|c|c|c|c|c|c|c|}
\hline \multirow[t]{3}{*}{ Year } & \multicolumn{3}{|c|}{ Stock firms } & \multicolumn{3}{|c|}{ Mutual firms } \\
\hline & \multirow[t]{2}{*}{$N$} & \multicolumn{2}{|c|}{ Market share (\%) } & \multirow[t]{2}{*}{$N$} & \multicolumn{2}{|c|}{ Market share (\%) } \\
\hline & & Assets & Premiums written & & Assets & Premiums written \\
\hline 1993 & 1065 & 59.2 & 60.3 & 110 & 40.4 & 37.1 \\
\hline 1994 & 968 & 60.5 & 61.1 & 104 & 39.2 & 36.8 \\
\hline 1995 & 945 & 64.1 & 66.4 & 99 & 35.7 & 31.4 \\
\hline 1996 & 881 & 61.7 & 62.4 & 110 & 38.0 & 35.4 \\
\hline 1997 & 781 & 65.7 & 68.4 & 96 & 34.0 & 29.4 \\
\hline 1998 & 739 & 67.1 & 69.9 & 96 & 32.6 & 28.3 \\
\hline 1999 & 652 & 69.3 & 70.9 & 92 & 30.4 & 27.3 \\
\hline 2000 & 600 & 77.6 & 80.4 & 86 & 22.1 & 17.7 \\
\hline 2001 & 572 & 84.5 & 82.8 & 75 & 15.3 & 15.5 \\
\hline 2002 & 540 & 85.2 & 84.2 & 70 & 14.6 & 13.9 \\
\hline 2003 & 518 & 85.2 & 82.4 & 65 & 14.5 & 15.1 \\
\hline
\end{tabular}

Source: Organisational form, assets and premiums data are from NAIC data CDs 1993-2003. The statistics are based on unaffiliated single companies and insurance groups.

$t-1$, where the notation "year $t$ " refers to the year of demutualisation. We classify insurers into deciles based on total admitted assets. Matching firms are identified from the corresponding decile of the converting insurer; we chose those firms closest in direct premiums written. A pseudo-conversion year is then assigned to the matching mutual insurer for each converting firm. As stated in Viswanathan and Cummins, ${ }^{8}$ such a matching method controls for the size and premium activity of converting insurers and matching insurers, and thus allows our analyses to identify further what is special about the converting mutuals.

Financial data for our sample are obtained from NAIC regulatory annual statements. Corporate governance data, such as officer and board of director information, also come from NAIC. We cross-checked the data, especially the CEO information, with Best's Insurance Reports - Life/Health in various years. For firms that do not report CEO information, we use the information for their presidents instead. Data from 1990 to 2005 is used in the analysis.

We collected CEO age data from a wide range of sources, including Who's Who, $D \& B$ (National Edition), Zoominfo.com, Peoplefinder.com, Biography \& Genealogy Master Index and Forbes.com. Compensation data for CEOs were collected from various editions of the Insurance Forum. We also collected data on stock options and stock ownership awarded to CEOs and to directors and officers as a group from firm Securities and Exchange Commission (SEC) filings (Definitive Proxy Statement, DEF 14A) and COMPUSTAT executive compensation for at least six years after a firm's demutualisation. $^{37}$ This corporate governance data enables the adequate investigation of the managerial welfare hypothesis.

${ }^{37}$ According to the Insurance Forum, "total compensation" includes salary, bonuses and all other compensation (emoluments). For public firms, "total compensation" includes salary, bonuses, other 
Table 2 List of demutualisation firms, 1993-2003

\begin{tabular}{|c|c|}
\hline Demutualised life-health insurers & Conversion year \\
\hline Midland Mutual Life Insurance (Midland Life) & 1994 \\
\hline Connecticut American Life Ins Co. & 1995 \\
\hline State Mutual Life Assurance — Allmerica & 1995 go public \\
\hline Guarantee Mutual Life Insurance Company & 1995 go public \\
\hline Trigon Blue Cross and Blue Shield of Virginia & 1995 go public \\
\hline American Mutual Life Insurance Company & 1996 go public \\
\hline Acacia Mutual Life Insurance Company & 1997 \\
\hline Ameritas Life Insurance Corp & 1997 \\
\hline General American Life Insurance Company & 1997 go public ${ }^{\mathrm{a}}$ \\
\hline Pacific Mutual Life Insurance Co. & 1997 \\
\hline Minneasota Mutual Life Insurance Co. & 1998 \\
\hline Mutual Life Insurance Co. of New York (MONY) & 1998 go public \\
\hline Ohio National Life Insurance Company & 1998 \\
\hline Principle Mutual Life Insurance Company & 1998 \\
\hline Security Benefit Life Insurance Company & 1998 \\
\hline Canada Life Assurance Company & 1999 \\
\hline John Hancock Mutual Life Insurance Company & 1999 go public \\
\hline MTL Insurance Company & 1999 \\
\hline National life Insurance Company of Vermont & 1999 \\
\hline National Travelers Life Company & 1999 \\
\hline Standard Insurance Company & 1999 go public \\
\hline The Security Mutual Life Insurance Company & 1999 \\
\hline Trustmark Insurance Company (Mutual) & 1999 \\
\hline Woodmen Accident \& Life Co. & 1999 \\
\hline American United Life Insurance Co. & 2000 \\
\hline Baltimore Life Ins Co. & 2000 \\
\hline Indianapolis Life Insurance Co. & 2000 \\
\hline Lafayette Life Insurance Co. & 2000 \\
\hline Metropolitan Life Insurance Company (Met Life) & 2000 go public \\
\hline Phoenix Home Life Mutual Insurance Company & 2000 \\
\hline Principle Mutual Life Insurance Company & 2000 go public \\
\hline Lincoln Direct Life Ins Co. & 2001 \\
\hline Pioneer Mutual Life Insurance Co. & 2001 \\
\hline Prudential Insurance Company of America & 2001 go public \\
\hline The Western and Southern Life Insurance Company & 2001 \\
\hline United Heritage Life Ins Co. & 2001 \\
\hline Nationwide Life Ins Co. of America & 2002 go public ${ }^{\mathrm{b}}$ \\
\hline
\end{tabular}

${ }^{a}$ General American Life Insurance first reorganised into a mutual holding company in 1997, then immediately sought to convert to a full stock company by going public. However, the company became a subsidiary of Metropolitan Life Insurance Company in 1999 due to an unexpected liquidity crisis. MetLife completed IPO demutualisation in 2000, and General American Life Insurance was part of this demutualisation. Excluding this firm from the sample does not materially affect our results.

b The company's former name is Provident Mutual Life Insurance Company. In 2002, Provident Mutual Life Insurance Company conducted a demutualisation sponsored by Nationwide Financial Services, Inc. (NFS), a publicly traded firm, and concurrently merged with NFS. Excluding this firm from the sample does not materially affect our results.

Notes: Demutualisation information comes from Best's Insurance Report - Life/Health (2004) list of conversions section, cross-checked with Best's insurance reports on individual firms, NAIC statements, firm websites and lists of converting firms in Viswanathan and Cummins (2003) and Erhemjamts (2005). The IPO demutualisation list comes from Viswanathan (2006) and SNL Financial - Insurance Industry Vital Statistics. Conversion year is defined as the year a company decides to convert. 


\section{Efficiency estimation}

We use DEA, a non-parametric technique, to estimate firm efficiency. ${ }^{38}$ DEA constructs the efficient frontier (a convex hull) consisting of the "best practice" firms in an industry and compares all other firms in the industry to that frontier. Firms operating on the frontier are fully efficient (with efficiency scores of 1), and firms not on the frontier are inefficient (with efficiency scores between 0 and 1). The DEA method is superior to econometric frontier efficiency methods because it makes no assumptions regarding the production function, the cost function, or the probability distribution of the error terms, which prevents potential estimation bias caused by model misspecification. Previous studies have shown that DEA estimation has good asymptotic statistical properties, can better handle heteroscedasticity than econometric approaches, and also yields consistent estimators for contextual variables in the twostage regression with DEA efficiency as the dependent variable. ${ }^{39}$

Four inputs are used in efficiency estimation: administrative labour, agent labour, materials and business services, and financial equity capital. Following previous literature, the quantities of administrative labour, agent labour and business services are defined as the current dollar expenditures related to these inputs divided by their current prices. The prices for administrative labour and agent labour inputs are defined as the U.S. Department of Labor (DOL) average weekly wage (AWW) for employees in life insurance companies (Standard Industrial Classification (SIC) 6311 and NAICS 524113) and the DOL AWW for insurance agents (SIC 6411 and NAICS 524210), respectively. The price for materials and business services is calculated by taking the weighted average of price indices for business services from the component indices of various expenditures from the expense exhibit of Best's Aggregates and Averages. The base year for all price indices is the year 2000.

The quantity of financial equity capital input is defined as statutory policy-holder surplus plus mandatory securities valuation reserve, a reserve required by regulatory accounting but not recognised by generally accepted accounting principles. ${ }^{40}$ The average of beginning- and end-of-year equity capital is used as the insurer's capital for any given year, deflated by the consumer price index (CPI). Following the insurance literature, we adopted the size-adjusted capital asset pricing model based on data from Ibbotson Associates; ${ }^{41}$ that is, the cost of capital for year $t$ is calculated as the 30 -day Treasury bill rate at the end of year $t-1$, plus the long-term (1926 to the end of year $t-1)$

annual compensation, restricted stock awards, long-term incentive plan payouts and all other compensation, but it excludes the value of securities underlying stock options and the value of the option granted. When the figures for particular individuals differed from one document to another, the Forum reports the larger figures. Since the compensation data collected by the Forum does not include the value of stock options in earlier years (before 2002; after 2002, the Forum reports stock options separately from compensation), we collected stock option data from COMPUSTAT and proxy statements of firms (this data is only available for IPO demutualisation firms). We also collected the compensation data for " $t-1$ CEOs", both before demutualisation and after, whether or not they were still CEOs after demutualisation.

${ }^{38}$ See Cooper et al. (2000) and Cummins and Weiss (2000) for the details of mathematical programming of the DEA method.

39 Banker (1993), Banker et al. (2004), Banker and Natarajan (2008).

${ }^{40}$ Cummins et al. (2010).

${ }^{41}$ Ibbotson Associates (2008). 
average market risk premium on large company stocks, plus the long-term (1926 through the end of year $t-1$ ) average size premium from Ibbotson Associates. All insurers in the industry are classified into four size groups based on their equity capital. No size premium is assigned to the largest size category, and the Ibbotson long-term average size premium is assigned to each of the smaller size categories. ${ }^{42}$

We adopt a modified value-added approach to define insurance outputs, ${ }^{43}$ which considers those that have significant value added as important outputs, as judged using operating cost allocations. Three types of principal services are provided by insurance companies: risk pooling and risk bearing, "real" financial services related to insured losses, and financial intermediation services. As the products offered by life insurers differ in the types of contingent events related to the insurance services, we define five insurance output variables for the five major lines of business provided by life insurers: individual life insurance, individual annuities, group life insurance, group annuities and accident and health insurance. One intermediary output (invested assets) is defined for financial intermediation services provided by insurance companies.

We follow Cummins et al., ${ }^{40}$ and Berger et al., ${ }^{44}$ to measure the quantity of insurance output by using incurred benefits plus additions to reserves with respect to each particular output, deflated to the year 2000 dollar by CPI. Incurred benefits are useful proxies for the risk-pooling and risk-bearing functions because they measure the amount of funds pooled by life insurers and distributed to policy-holders as compensation for insured events. Both incurred benefits and additions to reserves are correlated with real services provided by insurers such as underwriting and actuary services, benefit administration, and financial planning services. ${ }^{45}$ The quantity of intermediation output is measured by the CPI-deflated average of the beginning- and end-of-year invested assets.

\section{Methodology}

Our analysis proceeds in three steps:

The first step examines the ex-ante determinants of demutualisation. Based on the discussions of the motivations of demutualisation, a univariate analysis and a logit regression are conducted (results in Tables 3 and 4). The logit model is

$$
\begin{aligned}
& \operatorname{Pr}\left(\text { CONVERT }_{i, t}=1\right)=F\left(\alpha+\beta_{1} \text { SACCOUNT }_{i, t}\right. \\
& +\beta_{2} F_{C F} F_{i, t}+\beta_{3} \text { RCAPITAL }_{i, t} \\
& +\beta_{4} \text { REINSURE }_{i, t}+\beta_{5} \text { PGROUP }_{i, t} \\
& +\beta_{6} \text { PHERF }_{i, t}+\beta_{7} \text { GHERF }_{i, t}+\beta_{8} \text { GROWTH }_{i, t} \\
& +\beta_{9} E F F_{i, t}+\beta_{10} \text { BOARDSIZE } E_{i, t} \\
& +\beta_{11} \text { OUTDIRECTOR } R_{i, t}+\beta_{12} \text { CEO_Age } e_{i, t} \\
& +\beta_{13} \text { CEO_Tenure }{ }_{i, t}+\beta_{14} \text { GLBA) }
\end{aligned}
$$

${ }^{42}$ Cummins and Xie (2008).

${ }^{43}$ Cummins et al. (2010), Berger et al. (2000), Cummins et al. (1999).

${ }^{44}$ Berger et al. (2000).

${ }^{45}$ In earlier efficiency studies, researchers sometimes used premiums as a measure of insurance output; however, premiums represent revenues, that is, price multiplied by quantity, rather than quantity alone (Yuengert, 1993). 


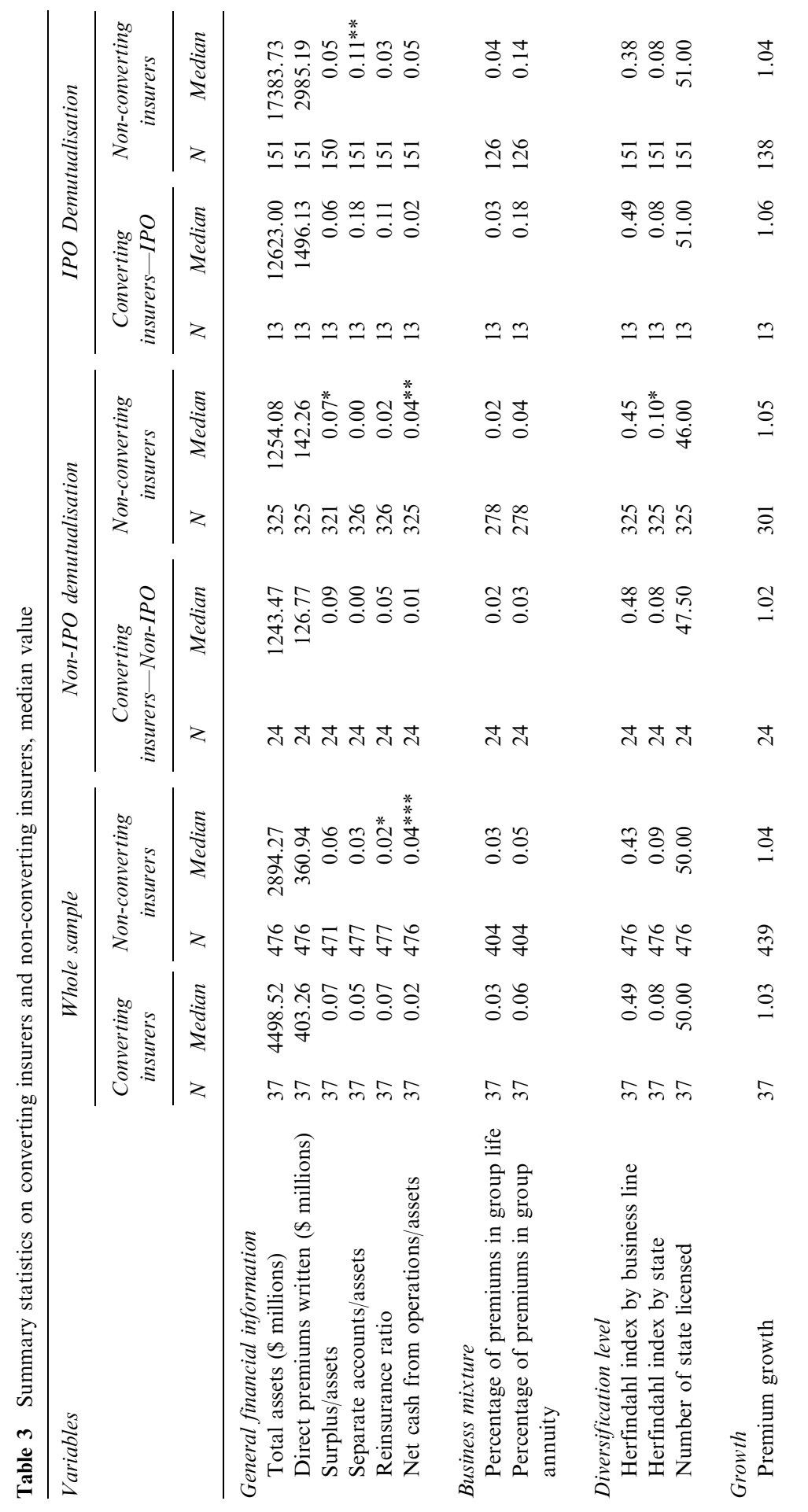




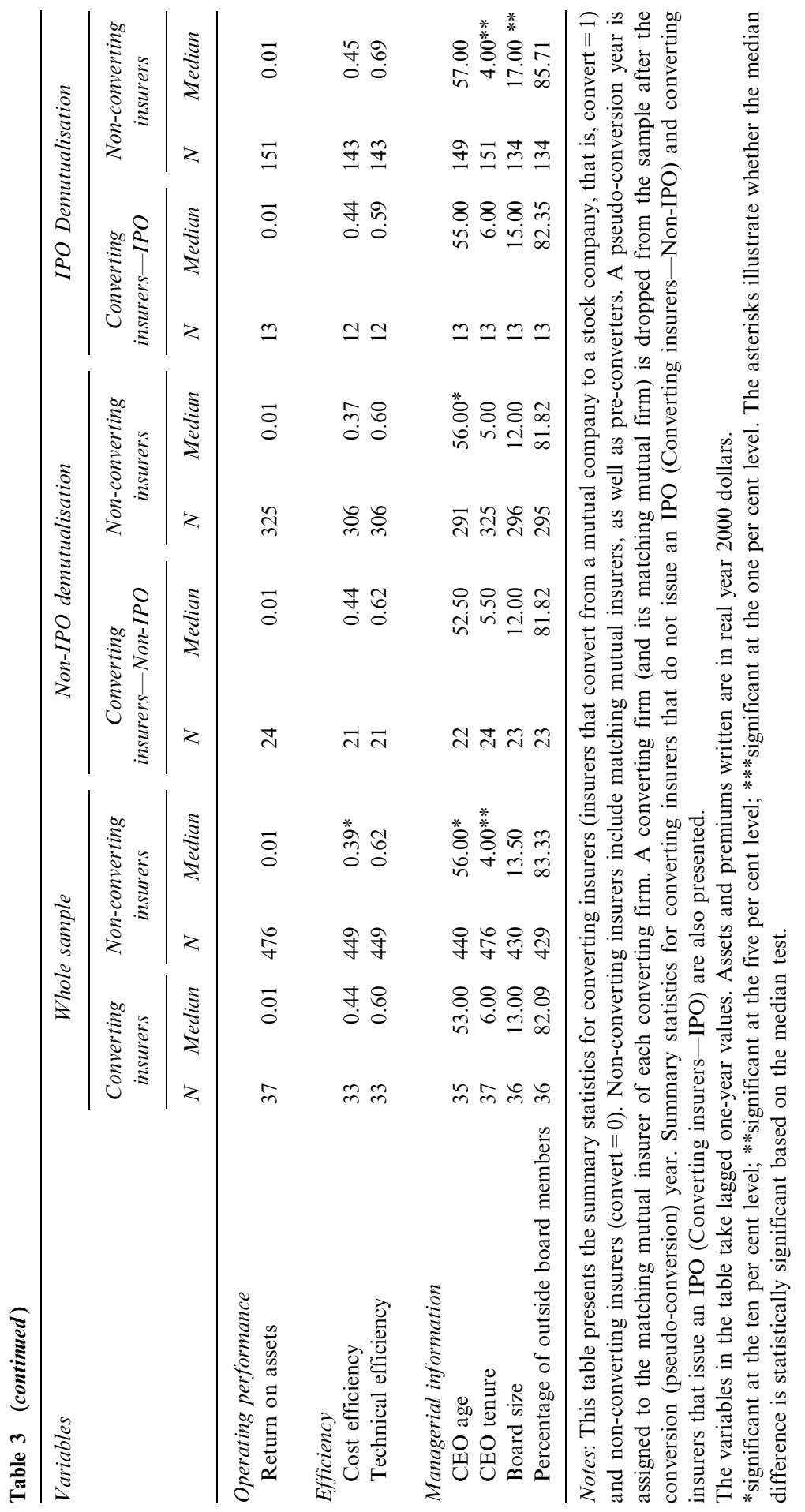


Table 4 Logistic regression on determinants of demutualisation

\begin{tabular}{|c|c|c|c|c|c|c|}
\hline \multirow[t]{2}{*}{ Variables } & \multicolumn{3}{|c|}{ Model 1} & \multicolumn{3}{|c|}{ Model 2} \\
\hline & $\begin{array}{l}\text { Whole } \\
\text { sample }\end{array}$ & $I P O$ & Non-IPO & $\begin{array}{l}\text { Whole } \\
\text { sample }\end{array}$ & $I P O$ & Non-IPO \\
\hline Separate accounts/assets & $\begin{array}{c}0.835 \\
{[1.616]}\end{array}$ & $\begin{array}{c}\text { 11.359* } \\
{[6.691]}\end{array}$ & $\begin{array}{c}-3.278 \\
{[2.329]}\end{array}$ & $\begin{array}{c}0.616 \\
{[1.645]}\end{array}$ & $\begin{array}{c}33.846^{* *} \\
{[15.402]}\end{array}$ & $\begin{array}{c}-3.830 \\
{[2.464]}\end{array}$ \\
\hline Net cash from operations/assets & $\begin{array}{l}-4.044 \\
{[7.079]}\end{array}$ & $\begin{array}{c}1.777 \\
{[18.733]}\end{array}$ & $\begin{array}{r}-21.010 * \\
{[12.227]}\end{array}$ & $\begin{array}{c}-3.451 \\
{[7.038]}\end{array}$ & $\begin{array}{c}21.760 \\
{[25.929]}\end{array}$ & $\begin{array}{r}-20.936^{*} \\
{[12.080]}\end{array}$ \\
\hline Surplus/assets & $\begin{array}{l}\mathbf{8 . 1 4 1 * *} \\
{[3.680]}\end{array}$ & $\begin{array}{c}17.156 \\
{[20.398]}\end{array}$ & $\begin{array}{c}7.536 \\
{[5.005]}\end{array}$ & $\begin{array}{c}\mathbf{7 . 0 1 8} * \\
{[3.895]}\end{array}$ & $\begin{array}{c}46.292 \\
{[33.712]}\end{array}$ & $\begin{array}{c}6.087 \\
{[5.451]}\end{array}$ \\
\hline Reinsurance ratio & $\begin{array}{l}3.292 * * \\
{[1.566]}\end{array}$ & $\begin{array}{c}8.457 \\
{[5.753]}\end{array}$ & $\begin{array}{c}3.632 * \\
{[2.144]}\end{array}$ & $\begin{array}{c}\mathbf{3 . 4 6 4}^{* *} \\
{[1.577]}\end{array}$ & $\begin{array}{c}2.792 \\
{[5.621]}\end{array}$ & $\begin{array}{c}\text { 3.883* } \\
{[2.153]}\end{array}$ \\
\hline Percentage of premiums in group insurance & $\begin{array}{c}0.830 \\
{[1.094]}\end{array}$ & $\begin{array}{c}3.241 \\
{[3.089]}\end{array}$ & $\begin{array}{c}0.536 \\
{[1.739]}\end{array}$ & $\begin{array}{c}1.147 \\
{[1.120]}\end{array}$ & $\begin{array}{c}4.291 \\
{[3.309]}\end{array}$ & $\begin{array}{c}0.869 \\
{[1.776]}\end{array}$ \\
\hline Herfindahl Index by business line & $\begin{array}{c}-0.666 \\
{[1.314]}\end{array}$ & $\begin{array}{c}-1.945 \\
{[3.996]}\end{array}$ & $\begin{array}{c}-1.268 \\
{[1.781]}\end{array}$ & $\begin{array}{r}-0.484 \\
{[1.332]}\end{array}$ & $\begin{array}{r}-9.956 \\
{[6.615]}\end{array}$ & $\begin{array}{c}-0.992 \\
{[1.820]}\end{array}$ \\
\hline Herfindahl Index by state & $\begin{array}{c}-1.636 \\
{[1.948]}\end{array}$ & $\begin{array}{c}-1.015 \\
{[8.933]}\end{array}$ & $\begin{array}{c}-\mathbf{1 5 . 0 9 4 * *} \\
{[7.257]}\end{array}$ & $\begin{array}{c}-1.239 \\
{[2.053]}\end{array}$ & $\begin{array}{l}-5.203 \\
{[12.431]}\end{array}$ & $\begin{array}{c}-15.775 * * \\
{[7.392]}\end{array}$ \\
\hline Premium growth & $\begin{array}{c}0.908 \\
{[0.862]}\end{array}$ & $\begin{array}{c}2.479 \\
{[2.045]}\end{array}$ & $\begin{array}{c}1.778 \\
{[1.247]}\end{array}$ & $\begin{array}{c}0.993 \\
{[0.864]}\end{array}$ & $\begin{array}{c}1.784 \\
{[2.517]}\end{array}$ & $\begin{array}{c}1.994 \\
{[1.301]}\end{array}$ \\
\hline Technical efficiency & & & & $\begin{array}{c}-1.070 \\
{[1.405]}\end{array}$ & $\begin{array}{c}-13.176 * * \\
{[5.896]}\end{array}$ & $\begin{array}{c}-1.527 \\
{[2.139]}\end{array}$ \\
\hline Cost efficiency & $\begin{array}{c}-0.103 \\
{[1.456]}\end{array}$ & $\begin{array}{c}-1.127 \\
{[3.158]}\end{array}$ & $\begin{array}{c}-0.569 \\
{[2.388]}\end{array}$ & & & \\
\hline Board size & $\begin{array}{c}-0.083 \\
{[0.056]}\end{array}$ & $\begin{array}{c}-\mathbf{0 . 3 2 1} * * \\
{[0.160]}\end{array}$ & $* \begin{array}{c}-0.121 \\
{[0.101]}\end{array}$ & $\begin{array}{c}-0.074 \\
{[0.057]}\end{array}$ & $\begin{array}{c}-\mathbf{0 . 5 5 7} * * \\
{[0.254]}\end{array}$ & $\begin{array}{c}-0.116 \\
{[0.100]}\end{array}$ \\
\hline Percentage of outside board members & $\begin{array}{c}0.014 \\
{[0.012]}\end{array}$ & $\begin{array}{c}0.011 \\
{[0.036]}\end{array}$ & $\begin{array}{c}0.016 \\
{[0.014]}\end{array}$ & $\begin{array}{c}0.014 \\
{[0.012]}\end{array}$ & $\begin{array}{c}0.015 \\
{[0.041]}\end{array}$ & $\begin{array}{c}0.017 \\
{[0.014]}\end{array}$ \\
\hline CEO age & $\begin{array}{c}-\mathbf{0 . 0 7 0} * \\
{[0.039]}\end{array}$ & $\begin{array}{c}-0.053 \\
{[0.150]}\end{array}$ & $\begin{array}{c}-\mathbf{0 . 1 1 1} * \\
{[0.057]}\end{array}$ & $\begin{array}{c}-\mathbf{0 . 0 7 0 *} \\
{[0.039]}\end{array}$ & $\begin{array}{c}-0.224 \\
{[0.219]}\end{array}$ & $\begin{array}{c}-\mathbf{0 . 1 1 1} * * \\
{[0.057]}\end{array}$ \\
\hline CEO tenure & $\begin{array}{l}\text { 0.110** } \\
{[0.050]}\end{array}$ & $\begin{array}{l}\mathbf{0 . 2 6 6}^{* *} \\
{[0.128]}\end{array}$ & $\begin{array}{c}\mathbf{0 . 1 5 0} \\
{[0.081]}\end{array}$ & $\begin{array}{l}\text { 0.108** } \\
{[0.050]}\end{array}$ & $\begin{array}{l}\text { 0.566** } \\
{[0.254]}\end{array}$ & $\begin{array}{r}\mathbf{0 . 1 5 2} \\
{[0.082]}\end{array}$ \\
\hline GLBA dummy & $\begin{array}{l}\mathbf{2 . 1 8 4} \% * \% \\
{[0.520]}\end{array}$ & $\begin{array}{c}\mathbf{3 . 0 6 3}^{* *} \\
{[1.272]}\end{array}$ & $\begin{array}{l}\text { 2.339*** } \\
{[0.668]}\end{array}$ & $\begin{array}{l}2.270 \% * * \\
{[0.524]}\end{array}$ & $\begin{array}{c}\mathbf{3 . 9 8 2}^{\circ} * \\
{[1.582]}\end{array}$ & $\begin{array}{l}\mathbf{2 . 4 5 5} \% * * \\
{[0.693]}\end{array}$ \\
\hline Constant & $\begin{array}{c}-1.141 \\
{[2.405]}\end{array}$ & $\begin{array}{l}-3.514 \\
{[8.925]}\end{array}$ & $\begin{array}{l}2.673 \\
{[3.419]}\end{array}$ & $\begin{array}{l}-0.803 \\
{[2.405]}\end{array}$ & $\begin{array}{c}13.031 \\
{[14.233]}\end{array}$ & $\begin{array}{c}3.006 \\
{[3.334]}\end{array}$ \\
\hline Observations & 374 & 126 & 248 & 374 & 126 & 248 \\
\hline Log likelihood & -90.51 & -23.75 & -52.11 & -90.22 & -19.33 & -51.88 \\
\hline $\begin{array}{l}\text { Likelihood-ratio test of equality of } \\
\text { coefficients }\end{array}$ & & 29.30 & & & 38.03 & \\
\hline$P$-value & & 0.0147 & & & 0.0009 & \\
\hline
\end{tabular}

Notes: This table presents the logistic regression to test the factors associated with a firm's decision for demutualisation. The dependent variable is 1 for converting insurers at the converting year and 0 for matching mutual insurers and pre-converters. A pseudo-conversion year is assigned to the matching mutual insurer of each converting firm. A converting firm (and its matching mutual firm) is dropped from the sample after the conversion (pseudo-conversion) year. The "IPO" sample refers to IPO demutualisation firms and their matching mutuals, and the "non-IPO" sample is restricted to non-IPO demutualisation firms and their matching mutuals. The independent variables take lagged one-year values. The Gramm-LeachBliley Act (GLBA) dummy equals 1 if year $\geqslant 1999$, and 0 otherwise.

*significant at the ten per cent level; **significant at the five per cent level; ***significant at the one per cent level. Standard errors are in brackets.

Bold indicates at least marginal significance as noted below the table. 
where $i$ represents insurer, $t$ represents year and, $C O N V E R T_{i, t}=0$ if a company $i$ stays mutual in year $t$ and equals 1 if it demutualises that year; $S A C C O U N T=$ separate accounts/assets, percentage of assets in separate accounts; $F C F=$ net cash from operations/assets; $R C A P I T A L=$ surplus/assets, surplus-to-assets ratio; REINSURE $=$ reinsurance ratio, defined as net reinsurance transaction/direct premiums written; $G R O U P=$ percentage of premiums in group insurance (including group life and group annuity); $P H E R F=$ Herfindahl Index by business lines, based on net premiums written; $G H E R F=$ Herfindahl Index across states, based on net premiums written; $G R O W T H=$ premium growth, defined as net premiums written $(t) /$ net premiums written $(t-1) ; E F F=$ efficiency score (cost or technical efficiency) generated by DEA; $B O A R D S I Z E=$ board size, number of board directors; OUTDIRECTOR=percentage of outside board members; ${ }^{46} C E O \_A g e=C E O ' s$ age; $C E O \_$Tenure $=$number of years that the $\mathrm{CEO}$ has served as $\mathrm{CEO}$; and $G L B A=$ Gramm-Leach-Bliley Act dummy, equals 1 if year $\geqslant 1999$, and 0 otherwise.

Similar to the design of Pagano et al., ${ }^{47}$ at any time $t$, the CONVERT $=0$ sample includes all matching mutual insurers in that year and converting firms that stayed mutual in that year. A demutualised firm (and its matching mutual firm) is dropped from the sample after the conversion (pseudo-conversion) year. ${ }^{48}$ Lagged values of the regressors are used in the regression.

The second step evaluates the effect of demutualisation on firm performance and financial characteristics (results reported in Table 5). Following Pagano et al., ${ }^{47}$ we construct an unbalanced panel sample for all demutualisation firms and matching mutual firms. Fixed-effects regressions are then estimated, and the effects of demutualisation are captured by dummy variables for the year of the conversion, as well as subsequent years. The model specification is as follows:

$$
\begin{aligned}
y_{i, t}=\alpha & +\sum_{j=0}^{3} \beta_{j} \operatorname{CONVERT}_{t-j} \\
& +\beta_{4} \text { CONVERT }_{t-n}+\gamma_{t} \text { Controls }_{i, t} \\
& +\mu_{i}+d_{t}+\varepsilon_{i, t}
\end{aligned}
$$

where $i$ represents insurer, $t$ represents year, and $\mu_{i}$ and $d_{t}$ are firm-specific and calendar-year-specific effects, respectively. $C O N V E R T_{t-j}$ is a dummy variable equal to one, if year $t-j$ was the demutualisation year. $C O N V E R T_{t-n}$ is a dummy variable equal to one, if the demutualisation took place more than three years before $t$.

\footnotetext{
${ }^{46}$ The percentage of outside board members is calculated as the number of outside directors divided by board size. Outside directors are defined as directors who are not inside directors. Following He and Sommer (2006), we define inside directors as those who are also officers of the firm or have the same last name as the officers. Since the majority of firms in our sample are private companies, we were unable to obtain more detailed information such as whether the directors are friends of officers, employees or business partners of the firms.

47 Pagano et al. (1998).

48 That is, the "non-converting insurers" (CONVERT=0 sample) include matching mutual firm-years until the pseudo-conversion years and demutualisation firm-years before conversion.
} 
The design of this model enables use of a pre-conversion firm as a control for itself after the deal. It also allows separation of the short-term and long-term effects, which could be mutually offsetting. ${ }^{49}$ To control for outliers, the robust regression method is used. $^{50}$

The dependent variables $y_{i t}$ include performance of the firm (cost efficiency, technical efficiency and return on assets) and important financial characteristics $(F C F$ and $R C A P I T A L)$. The control variables in these regressions include firm size, lagged values of the dependent variable and other variables that may be relevant such as business mix, firm diversification level and premium growth. Surplus-to-assets ratio (RCAPITAL) is also controlled in the regressions, except for its own regression. ${ }^{51}$ These variables are written as "Controls" in Eq. (2).

The third step analyzes details of the management structure and CEO compensation before and after demutualisation to further test the management welfare hypothesis. The impact of post-demutualisation turnover on firm performance is also included in this section. The corresponding results are reported in Table 6.

The model specifications for regression analyses of managerial information are similar to the ones described in Eq. (2), where the dependent variables are now BOARDSIZE, OUTDIRECTOR, INSALARY, INSALARYOPT and INSALARYCEOIOPT, with INSALARY=Logarithm value of CEO compensation (no stock option value); INSALARYOPT=Logarithm value of CEO compensation (with stock option value); and INSALARYCEO1OPT=Logarithm value of " $t-1$ CEO" compensation (with stock option value).

Following the corporate governance literature, ${ }^{52}$ size, lagged values of the dependent variable, business mix and firm diversification level (which represents the scope of operations of a firm) are controlled in the BOARDSIZE and OUT$D I R E C T O R$ regression. Premium growth and surplus-to-assets ratio are also controlled in the BOARDSIZE regression, and premium growth and net cash from operations/assets are controlled in the OUTDIRECTOR regression.

Three regressions with respect to CEO compensation are conducted: INSALARY INSALARYOPT and INSALARYCEOIOPT. Factors that affect CEO compensation such as size, lagged values of the compensation, lagged performance of firm, board size, fraction of independent directors, CEO age and tenure and turnover are controlled in the regression. ${ }^{53}$

Since CEO turnover is a dummy variable, the robust regression model cannot apply. Alternatively, we run a logistic regression to investigate the impact of demutualisation

${ }^{49}$ In an earlier version of the paper, we perform all the analyses using a method exactly mirroring that of Viswanathan and Cummins (2003) and reach the same conclusion. We adopt this fixed-effects method using panel data for the advantages described in Pagano et al. (1998).

${ }^{50}$ Robust regression method uses iteratively reweighted least squares, that is, it assigns a weight to each observation, with higher weights given to better behaved observations. Very extreme cases, for example, those with Cook's D $>1$, could be dropped from the regression altogether. Robust regression method can achieve almost the efficiency of OLS with ideal data and perform substantially better than OLS in non-ideal situations (e.g., non-normal errors or when samples often contain outliers) (Hamilton, 2003).

51 Similar to the practice in Pagano et al. (1998).

${ }^{52}$ Linck et al. (2008), Fernandes et al. (2008).

${ }^{53}$ Fernandes et al. (2008). 
Table 5 Effects of demutualisation on firm performance and financials

\begin{tabular}{|c|c|c|c|c|c|c|c|c|}
\hline Variables & $\begin{array}{l}\text { Sample used } \\
\text { (observations) }\end{array}$ & $\begin{array}{c}\text { Year } \\
0\end{array}$ & $\begin{array}{c}\text { Year } \\
+1\end{array}$ & $\begin{array}{l}\text { Year } \\
+2\end{array}$ & $\begin{array}{c}\text { Year } \\
+3\end{array}$ & $\begin{array}{c}\text { Year }> \\
+3\end{array}$ & $\begin{array}{c}F \text {-test } \\
\text { (1) }\end{array}$ & $\begin{array}{c}F \text {-test } \\
\text { (2) }\end{array}$ \\
\hline \multicolumn{9}{|l|}{ Panel A: Efficiency } \\
\hline \multirow[t]{6}{*}{ Cost efficiency } & Whole sample & $0.037 * *$ & 0.020 & 0.013 & 0.005 & 0.002 & 0.2461 & 0.3294 \\
\hline & 884 & {$[0.017]$} & {$[0.016]$} & {$[0.017]$} & {$[0.017]$} & {$[0.015]$} & & \\
\hline & IPO & $0.073^{* *}$ & 0.027 & $0.074 * *$ & 0.003 & 0.025 & 0.0251 & 0.0484 \\
\hline & 311 & {$[0.028]$} & {$[0.029]$} & {$[0.030]$} & {$[0.032]$} & {$[0.029]$} & & \\
\hline & Non-IPO & -0.009 & 0.004 & -0.013 & -0.001 & -0.006 & 0.9528 & 0.9813 \\
\hline & 573 & {$[0.020]$} & {$[0.019]$} & {$[0.020]$} & [0.019] & {$[0.017]$} & & \\
\hline \multirow[t]{6}{*}{ Technical efficiency } & Whole sample & 0.008 & 0.006 & 0.012 & -0.011 & 0.000 & 0.8860 & 0.9493 \\
\hline & 884 & {$[0.020]$} & {$[0.019]$} & {$[0.020]$} & {$[0.020]$} & {$[0.017]$} & & \\
\hline & IPO & 0.019 & -0.028 & 0.015 & -0.060 & -0.006 & 0.3176 & 0.4348 \\
\hline & 310 & {$[0.034]$} & {$[0.035]$} & [0.037] & [0.038] & {$[0.035]$} & & \\
\hline & Non-IPO & -0.018 & 0.024 & 0.015 & 0.025 & 0.021 & 0.5246 & 0.6228 \\
\hline & 574 & {$[0.024]$} & {$[0.023]$} & {$[0.025]$} & {$[0.024]$} & {$[0.021]$} & & \\
\hline \multicolumn{9}{|c|}{ Panel B: Operating performance } \\
\hline \multirow[t]{6}{*}{ Return on assets } & Whole sample & 0.001 & 0.001 & $0.003 * * *$ & 0.001 & $0.002 * *$ & 0.0196 & 0.0242 \\
\hline & 972 & {$[0.001]$} & {$[0.001]$} & {$[0.001]$} & {$[0.001]$} & {$[0.001]$} & & \\
\hline & IPO & 0.001 & 0.002 & $0.006 * * *$ & 0.001 & $0.003 * *$ & 0.0033 & 0.0047 \\
\hline & 334 & {$[0.001]$} & {$[0.001]$} & {$[0.001]$} & {$[0.002]$} & {$[0.001]$} & & \\
\hline & Non-IPO & 0.000 & 0.000 & 0.001 & 0.001 & 0.001 & 0.9543 & 0.9813 \\
\hline & 638 & {$[0.001]$} & {$[0.001]$} & {$[0.001]$} & {$[0.001]$} & {$[0.001]$} & & \\
\hline \multicolumn{9}{|c|}{ Panel C: Financial characteristics } \\
\hline \multirow{6}{*}{$\begin{array}{l}\text { Net cash from } \\
\text { operations/assets }\end{array}$} & Whole sample & -0.005 & 0.001 & $-0.010 * * *$ & 0.001 & 0.001 & 0.0430 & 0.0455 \\
\hline & 973 & {$[0.004]$} & {$[0.004]$} & {$[0.004]$} & {$[0.004]$} & {$[0.003]$} & & \\
\hline & IPO & -0.007 & 0.000 & $-0.013 * *$ & $-0.020 * * *$ & -0.007 & 0.0092 & 0.0184 \\
\hline & 334 & {$[0.006]$} & {$[0.006]$} & [0.006] & {$[0.006]$} & {$[0.005]$} & & \\
\hline & Non-IPO & -0.003 & 0.001 & $-0.010 * *$ & 0.010 ** & 0.003 & 0.0187 & 0.0322 \\
\hline & 639 & {$[0.005]$} & {$[0.005]$} & {$[0.005]$} & {$[0.005]$} & [0.004] & & \\
\hline \multirow[t]{6}{*}{ Surplus/assets } & Whole sample & $-0.003^{*}$ & -0.003 & 0.001 & -0.002 & -0.001 & 0.1414 & 0.2210 \\
\hline & 968 & {$[0.002]$} & {$[0.002]$} & {$[0.002]$} & {$[0.002]$} & {$[0.001]$} & & \\
\hline & IPO & -0.002 & -0.004 & $-0.008 * *$ & $-0.006 *$ & $-0.015 * * *$ & 0.1406 & 0.0001 \\
\hline & 333 & [0.003] & {$[0.003]$} & {$[0.004]$} & [0.004] & {$[0.003]$} & & \\
\hline & Non-IPO & -0.003 & -0.002 & 0.002 & -0.001 & $0.004 * *$ & 0.3235 & 0.0131 \\
\hline & 635 & {$[0.002]$} & {$[0.002]$} & {$[0.002]$} & {$[0.002]$} & {$[0.002]$} & & \\
\hline
\end{tabular}

Notes: This table presents the fixed effect regression for the effects of demutualisation on firm performance and financials. The key independent variables are the post-demutualisation dummies (which are reported in the table). Constant terms and control variables are not reported (see Section 'Methodology' for a detailed discussion).

F-test (1) tests the hypothesis that the sum of the coefficients of the post-demutualisation dummies (within three years) is equal to 0 ( $P$-value is reported). $F$-test $(2)$ tests the hypothesis that the sum of the coefficients of all the post-demutualisation dummies is equal to 0 ( $P$-value is reported).

*significant at the ten per cent level; **significant at the five per cent level; ***significant at the one per cent level. Standard errors in brackets.

Bold indicates at least marginal significance as noted below the table.

on CEO turnover. The model specification is:

$$
\begin{aligned}
\operatorname{Pr}\left(\text { Turnover }_{i, t}=1\right)=F(\alpha & +\beta_{1} \text { CONVERT }_{t-n 1}+\beta_{2} \text { CONVERT }_{t-n 2} \\
& \left.+\gamma_{t} \text { Controls }_{i, t}+\text { YearDummies }+\varepsilon_{i, t}\right)
\end{aligned}
$$


where $i$ represents insurer, $t$ represents year, and $C O N V E R T_{t-n 1}$ is a dummy variable equal to one, if the demutualisation took place no more than three years before $t,{ }^{54}$ while CONVERT $T_{t-n 2}$ is a dummy variable equal to one if the demutualisation took place more than three years before $t$. Following CEO turnover literature, the "controls" in the model include lagged value of firm performance, firm size, business mix, firm diversification, surplus-to-assets ratio, premium growth, CEO age, CEO tenure, lagged value of board size and fraction of independent directors. ${ }^{55}$

To address whether post-demutualisation turnover helps improve firm efficiency, we perform a fixed effect analysis by adding the interaction term of the postdemutualisation dummy and the turnover dummy, that is,

$$
\begin{aligned}
\text { EFF }_{i, t}= & \alpha+\sum_{j=0}^{3} \beta_{j} \text { CONVERT }_{t-j} \\
& +\beta_{4} \text { CONVERT }_{t-n} \\
& +\sum_{j=0}^{3} \phi_{j} \text { CONVERT }_{t-j} \times \text { Turnover }_{i, t} \\
& +\phi_{4} \text { CONVERT }_{t-n} \times \text { Turnover }_{i, t} \\
& +\mu_{i}+d_{t}+\varepsilon_{i, t}
\end{aligned}
$$

where $E F F_{i, t}$ refers to cost efficiency or technical efficiency for firm $i$ at time $t$.

\section{Determinants of demutualisation}

Table 3 reports the median value of firm characteristics for the converting and non-converting insurers before the conversion years. For the whole sample, the median converting firm has a higher reinsurance ratio than the median non-converting firm (0.07 vs. 0.02), ${ }^{56}$ but its cash from operations-to-assets ratio is lower than the median non-converting firm (0.02 vs. 0.04$)$. The median converting firm also has a higher cost efficiency score than the median non-converter (0.44 vs. 0.39$)$. In addition, the CEO of the median converting firm is found to be younger and of longer tenure than that of the median non-converter.

We further examine the characteristics by separating IPO demutualisation and non-IPO demutualisation. Compared to the median non-converting firm, the median

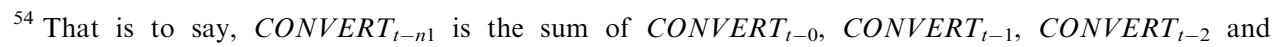
$C O N V E R T_{t-3}$. The purpose of the combination is to prevent prediction failure and keep as many observations in the sample as possible.

${ }^{55}$ Weisbach (1988), Murphy and Zimmerman (1993), Hadlock and Lumer (1997), Goyal and Park (2002).

${ }^{56}$ Despite the capital need argument for the usage of reinsurance, it is also possible that a higher reinsurance ratio reflects the "window dressing" behavior of converting firms. The organisations that demutualise undergo additional regulatory scrutiny before the conversion is approved. These organisations may have some "clean-up" done in preparation for the increased scrutiny. The greater use of reinsurance may reflect their greater risk aversion until the conversion is approved. We thank a referee for providing this comment. 
non-IPO converting firm tends to have a marginally higher surplus-to-assets ratio (0.09 vs. 0.07), a lower net cash from operations-to-assets ratio (0.01 vs. 0.04$)$, a younger $\mathrm{CEO}$, and more diversification across geographical areas (with a Herfindahl index of 0.08 vs. 0.10). The median IPO converting firm has a higher separate accounts-to-assets ratio (0.18 vs. 0.11), a smaller board, and a CEO of longer tenure.

Table 4 presents logit regression results for the determinants of demutualisation. Model 1 uses cost efficiency as an independent variable, and model 2 uses technical efficiency as an explanatory variable. The results for the whole sample (pooling IPO demutualisation and non-IPO demutualisation) show that those firms with higher reinsurance ratios and higher surplus-to-assets ratios are more likely to demutualise, supporting the access-to-capital element of the efficiency hypothesis. Higher preconversion surplus-to-assets ratios suggest that such firms may convert to obtain additional funds for external purposes (e.g., business expansion or acquisition), not to shore-up their financial positions, as argued in Section "Access to capital, growth and managerial discretion". In regard to corporate governance variables, we find a significant negative relationship between CEO age and the likelihood of demutualisation, suggesting that younger CEOs are more likely to demutualise. The tenure of CEOs in their current positions is positively related to the demutualisation decision.

Further insights on the determinants of demutualisation can be obtained by dividing the sample between IPO demutualisation and non-IPO demutualisation. A likelihood ratio test rejects the equality of the coefficients in the two subsamples at the five per cent level and at the one per cent level in models 1 and 2, respectively, suggesting that the differences are significant.

The non-IPO regression shows that firms with restricted cash flow, higher reinsurance ratios and greater geographical diversification are more likely to pursue a non-IPO demutualisation. The CEOs of such firms are younger but with longer tenure. The IPO regression shows that IPO demutualisation firms tend to have higher separate accounts-to-assets ratios, smaller boards and CEOs with longer tenure. They are also less technically efficient than the non-converting firms. These results indicate that one potential purpose of IPO demutualisation is to gain better skills and more resources for managing complex products. The smaller boards of IPO firms suggest that such firms are more likely to make value-maximising decisions. ${ }^{57}$

Finally, the regressions show that firms have been more likely to demutualise after the passage of the Gramm-Leach-Bliley Act (GLBA) in 1999, suggesting that mutual firms convert to increase their ability to access the capital market and therefore better cope with the more competitive environment created by the GLBA for U.S. life insurers. ${ }^{58}$

\section{Effects of demutualisation on firm performance and financials}

To evaluate the demutualisation decision, it is essential to compare the ex post performance and financials of converting firms with firms that stayed mutual. We investigate this by estimating fixed-effects regressions in which the effect of

\footnotetext{
${ }^{57}$ Lipton and Lorsch (1992), Jensen (1993).

${ }^{58}$ Carow (2001).
} 
demutualisation is captured by dummy variables for the year of the conversion and the subsequent years. These results and $F$-tests of significance are reported in Table 5 , with separate analyses conducted for the entire sample, IPO demutualisation and non-IPO demutualisation.

Panel A of Table 5 shows that non-IPO demutualisation firms register no significant improvement in post-demutualisation cost efficiency and technical efficiency, but IPO demutualisation firms experience significant improvement in cost efficiency, suggesting that management with better access to (public) capital can be more efficient in minimising costs. However, in neither case does efficiency decrease.

Panel B demonstrates that the operating performance (measured by ROA) of IPO demutualisation insurers also improves significantly after demutualisation. The effects of this phenomenon are strong enough to be carried over to the whole sample, despite the insignificant results for non-IPO demutualisation firms. The improvement of efficiency and operating performance of IPO demutualisation firms is consistent with findings in Lai et al., ${ }^{9}$ which state that demutualisation IPOs outperform non-IPO firms in long-run stock returns, which is mainly attributable to improvement in post-demutualisation operating performance.

Panel $\mathrm{C}$ finds a decline of cash flow to assets ratio for demutualised firms after conversion; the decline is more significant in IPO firms. This finding provides some support for the free cash flow element of the efficiency hypothesis. ${ }^{59}$

The surplus-to-assets ratio of IPO demutualisation firms declines significantly after conversion, starting the second year after demutualisation. ${ }^{60}$ This finding, combined with a slightly higher surplus-to-assets ratio before demutualisation (see Table 3), suggests that there is little evidence of surplus management in IPO demutualisation life insurers. ${ }^{61}$ Non-IPO demutualisation firms experience no significant changes in this ratio in the short term, but the ratio increases after the fourth year of demutualisation.

The evidence to this point is consistent with demutualisation serving to enhance value for IPO demutualisation firms and being value-neutral for non-IPO

59 The reduction in free cash may also reflect the costs of conversions (e.g., cash distribution to policyholders) and costs of the stock issues (e.g., underwriting costs).

${ }^{60}$ Possible explanations for the post-conversion decline in the surplus-to-assets ratio include: (1) the expenses of conversions and costs for the stock issues, which tend to reduce the cash flow of firms immediately and therefore reduce the surplus of the firm; (2) the acquisition activities of demutualised IPO firms (e.g., Amerus, Guarantee Life Cos., John Hancock, MetLife, MONY and Prudential all engaged in frequent acquisition activities right after conversion to stock companies); and (3) lower access cost to the capital market. As argued in Harrington and Niehaus (2002), stock firms generally face lower costs in raising new capital than mutual firms do, so they tend to operate with a lower surplus-to-asset ratio in the long run. As holding more capital is costly, operating with a relatively lower surplus-to-asset ratio can help reduce costs for a company and enhance firm cost efficiency.

${ }^{61}$ This is opposite to the findings in the property-liability insurance industry by Mayers and Smith (2004), who found that surplus management occurs in the U.S. property-liability insurers' stock-charter conversions, with strongest evidence among firms where existing executives became the principal stockholders of the firms after conversion. In our sample, the IPO demutualisation firms are diversely held by their stockholders. Of the 24 non-IPO demutualisation firms, 19 use the mutual holding company structure in which there is no stock distribution. The remaining five firms fully demutualised to stock companies, but no dominant management ownership is found after the conversion (these firms distribute cash, stock or policy credit to existing policy-holders), according to Best's Insurance Reports. 
demutualisation firms. The ex post analysis on firm financials, combined with the exante determinants of the demutualisation, provides no support for the managerial welfare hypothesis.

\section{Managerial structure, demutualisation and efficiency improvement}

\section{Managerial structure}

Panel A of Table 6 reports the regression results on board and management. The changes are captured in several post-demutualisation dummies for the short-term and relatively long-term effects of demutualisation (the model specification is described in Section 'Methodology'). Consistent with the literature, ${ }^{62}$ the results show that converting firms (whole sample) experience decreases in both board size and percentage of independent directors and increases in the CEO turnover rate in both the short term and long term. The regressions for subsamples show that IPO firms experience no significant change in board size but show a slight increase in the fraction of independent directors, which is weakly significant at the ten per cent level (with an $F$-test of 0.0956). ${ }^{63}$ The CEO turnover rate is significantly higher than that of matching mutuals (with an $F$-test of 0.0097 ), especially in the long term, as shown by the significantly positive coefficient of the "year $>+3$ " dummy. Non-IPO demutualisation firms experience significant decreases in both their board size and the fraction of independent directors and a marginally significant increase in CEO turnover in the short term, which is shown by the "year 0-3" dummy. These results suggest that managers whose firms demutualise are unable to successfully entrench and protect themselves from job loss.

\section{CEO compensation}

One of the predictions of the managerial welfare hypothesis is that the CEOs of converting firms choose to demutualise to increase their personal compensation independent of firm performance. To test this, we conduct regression analyses for CEO compensation. The analysis is performed for all CEOs and the time $(t-1)$ CEO only, no matter whether they are replaced or not. Since incentive compensation (such as stock options) is available for CEOs of public firms, we collect such information for IPO demutualisation firms and perform the analysis for compensation with and without stock option values. ${ }^{64}$ If the managerial welfare hypothesis holds, we expect to observe a significant increase in compensation (but without efficiency or operating performance gains), especially for $t-1$ CEOs who made the demutualisation decisions.

${ }^{62}$ Mayers et al. (1997), Mayers and Smith (1986), McNamara and Rhee (1992).

${ }^{63}$ It is argued that the passage of the Sarbanes-Oxley Act of 2002 (SOX), which applies to stock companies and mandates independent board members on the audit committee, may force some of the insurers to increase the number (and percentage) of outside directors to comply with the SOX after their conversion. As a robustness check, we rerun the regression by excluding data since 2002 . The results are similar to the ones reported in this paper.

${ }^{64}$ Stock options are not feasible for private firms; however, this is not a major issue because contingent compensation is not prone to rent-seeking. Contingent compensation is a function of firm performance, and it should discourage managers from pursuing private benefits at the expense of the firm. 
Panel B of Table 6 shows that, although the converting firms in aggregate experience a significant increase in CEO compensation (without option value), the results are not significant in the two subsamples (IPO demutualisation and non-IPO demutualisation), as indicated by the $P$-value of the $F$-test. However, if we include option value in the compensation, then IPO demutualisation firms exhibit a significant increase in CEO compensation. This is no surprise, given IPO performance improvement after demutualisation (Table 5), suggesting that "good things come together"; it should not be regarded as evidence of the managerial welfare hypothesis, since options payoff only with increases in stock prices. No significant increase in compensation is found in

Table 6 Effects of demutualisation on firm managerial structure and CEO compensation

\begin{tabular}{|c|c|c|c|c|c|c|c|c|c|}
\hline Variables & $\begin{array}{l}\text { Sample used } \\
\text { (observations) }\end{array}$ & $\begin{array}{c}\text { Year } \\
0\end{array}$ & $\begin{array}{c}\text { Year } \\
+1\end{array}$ & $\begin{array}{c}\text { Year } \\
+2\end{array}$ & $\begin{array}{c}\text { Year } \\
+3\end{array}$ & $\begin{array}{c}\text { Year }> \\
\quad+3\end{array}$ & $\begin{array}{c}\text { Year } \\
0-3\end{array}$ & $\begin{array}{c}F \text {-test } \\
(1)\end{array}$ & $\begin{array}{c}F \text {-test } \\
(2)\end{array}$ \\
\hline \multicolumn{10}{|c|}{ Panel A: Managerial structure } \\
\hline \multirow{6}{*}{ Board size } & Whole sample & $-0.605 * *$ & $-0.447 *$ & $-0.517 * *$ & -0.423 & $-0.850 * * *$ & & 0.0423 & 0.0067 \\
\hline & 885 & {$[0.236]$} & {$[0.246]$} & {$[0.255]$} & {$[0.276]$} & {$[0.237]$} & & & \\
\hline & IPO & -0.364 & -0.214 & -0.666 & -0.707 & -0.506 & & 0.4829 & 0.6128 \\
\hline & 299 & [0.429] & {$[0.438]$} & {$[0.453]$} & {$[0.485]$} & [0.433] & & & \\
\hline & Non-IPO & $-0.589 * *$ & $-0.713 * * *$ & $-0.469 *$ & $-0.591 * *$ & $-0.985 * * *$ & & 0.0146 & 0.0017 \\
\hline & 586 & {$[0.244]$} & {$[0.258]$} & {$[0.270]$} & {$[0.294]$} & {$[0.256]$} & & & \\
\hline \multirow{6}{*}{$\begin{array}{l}\text { Percentage of } \\
\text { outside board } \\
\text { members }\end{array}$} & Whole sample & 0.122 & 0.190 & 0.218 & $-0.977 * *$ & $-0.600 *$ & & 0.0691 & 0.0585 \\
\hline & 811 & {$[0.369]$} & {$[0.359]$} & {$[0.378]$} & {$[0.402]$} & {$[0.360]$} & & & \\
\hline & IPO & 0.981 & $1.944 * *$ & 1.269 & -0.087 & -0.186 & & 0.0793 & 0.0956 \\
\hline & 283 & {$[0.768]$} & {$[0.786]$} & [0.819] & {$[0.878]$} & [0.824] & & & \\
\hline & Non-IPO & 0.343 & -0.288 & 0.692 & $-1.674 * * *$ & $-1.277 * *$ & & 0.0073 & 0.0017 \\
\hline & 528 & {$[0.527]$} & [0.493] & {$[0.533]$} & {$[0.561]$} & {$[0.498]$} & & & \\
\hline \multirow{6}{*}{$\begin{array}{l}\text { CEO turnover } \\
\text { rate }\end{array}$} & Whole sample & & & & & $1.116^{*}$ & $0.621 *$ & 0.0992 & 0.0695 \\
\hline & 738 & & & & & {$[0.575]$} & {$[0.377]$} & & \\
\hline & IPO & & & & & $3.114 * * *$ & -0.343 & 0.6214 & 0.0097 \\
\hline & 278 & & & & & {$[1.073]$} & [0.695] & & \\
\hline & Non-IPO & & & & & 0.009 & $0.969 *$ & 0.0641 & 0.1625 \\
\hline & 460 & & & & & {$[0.804]$} & {$[0.524]$} & & \\
\hline \multicolumn{10}{|c|}{ Panel B: CEO compensation } \\
\hline \multirow{6}{*}{$\begin{array}{l}\text { CEO } \\
\text { compensation } \\
\text { (no option } \\
\text { value) }\end{array}$} & Whole sample & $0.132 * *$ & 0.091 & 0.043 & $0.180 * * *$ & $0.108 *$ & & 0.0272 & 0.0491 \\
\hline & 382 & {$[0.056]$} & {$[0.056]$} & {$[0.061]$} & {$[0.065]$} & {$[0.061]$} & & & \\
\hline & IPO & 0.054 & $0.122 *$ & 0.083 & $0.183 * *$ & 0.093 & & 0.1518 & 0.2408 \\
\hline & 204 & {$[0.070]$} & {$[0.069]$} & {$[0.074]$} & {$[0.077]$} & [0.076] & & & \\
\hline & Non-IPO & 0.048 & -0.074 & $-0.211 * *$ & 0.019 & -0.129 & & 0.1125 & 0.1332 \\
\hline & 178 & [0.089] & {$[0.091]$} & {$[0.104]$} & [0.115] & {$[0.104]$} & & & \\
\hline \multirow{6}{*}{$\begin{array}{l}\text { CEO } \\
\text { compensation } \\
\text { (with option } \\
\text { value) }\end{array}$} & Whole sample & $0.140 * *$ & $0.164 * * *$ & $0.191 * * *$ & * $0.326 * * *$ & $0.166 * *$ & & 0.0001 & 0.0003 \\
\hline & 384 & {$[0.060]$} & {$[0.060]$} & {$[0.066]$} & {$[0.070]$} & {$[0.065]$} & & & \\
\hline & IPO & -0.020 & $0.242 * * *$ & $0.213 * * *$ & $* 0.491 * *$ & $0.198 * *$ & & 0.0000 & 0.0000 \\
\hline & 205 & {$[0.071]$} & {$[0.071]$} & {$[0.077]$} & {$[0.081]$} & {$[0.078]$} & & & \\
\hline & Non-IPO & 0.048 & -0.074 & $-0.211 * *$ & 0.019 & -0.129 & & 0.1125 & 0.1332 \\
\hline & 178 & [0.089] & {$[0.091]$} & {$[0.104]$} & {$[0.115]$} & [0.104] & & & \\
\hline \multirow{6}{*}{$\begin{array}{l}\text { Compensation } \\
\text { of " } t-1 \text { CEO" } \\
\text { (with option } \\
\text { value) }\end{array}$} & Whole sample & 0.075 & $0.124 * *$ & $0.125^{*}$ & 0.124 & 0.016 & & 0.2745 & 0.1399 \\
\hline & 291 & {$[0.061]$} & {$[0.063]$} & {$[0.068]$} & {$[0.076]$} & [0.078] & & & \\
\hline & IPO & 0.048 & $0.204 * * *$ & $0.233 * * *$ & $*-0.054$ & -0.010 & & 0.0009 & 0.0011 \\
\hline & 152 & {$[0.074]$} & {$[0.074]$} & [0.082] & [0.093] & [0.109] & & & \\
\hline & Non-IPO & 0.069 & -0.015 & -0.092 & 0.124 & -0.073 & & 0.1932 & 0.1639 \\
\hline & 139 & {$[0.087]$} & [0.096] & [0.102] & {$[0.110]$} & [0.108] & & & \\
\hline
\end{tabular}


Table 6 (continued)

\begin{tabular}{|c|c|c|c|c|c|c|c|c|}
\hline & $\begin{array}{l}\text { Sample used } \\
\text { (observations) }\end{array}$ & $\begin{array}{c}\text { Year } \\
0 \\
\text { *turnover }\end{array}$ & $\begin{array}{c}\text { Year } \\
+1 \\
\text { *turnover }\end{array}$ & $\begin{array}{c}\text { Year } \\
+2 \\
\text { *turnover }\end{array}$ & $\begin{array}{c}\text { Year } \\
+3 \\
\text { *turnover }\end{array}$ & $\begin{array}{c}\text { Year }> \\
+3 \\
* \text { turnover }\end{array}$ & $\begin{array}{c}F \text {-test } \\
(3)\end{array}$ & $\begin{array}{c}F \text {-test } \\
\text { (4) }\end{array}$ \\
\hline \multicolumn{9}{|c|}{ Panel C: Efficiency and firm turnover } \\
\hline \multirow[t]{5}{*}{ Cost efficiency } & $\begin{array}{l}\text { Whole sample } \\
885\end{array}$ & $\mathbf{0 . 2 8 6}^{* * *}$ & $\begin{array}{l}-0.028 \\
{[0.062]}\end{array}$ & $\begin{array}{l}-0.023 \\
{[0.062]}\end{array}$ & $\mathbf{0 . 3 2 4} * * *$ & $\begin{array}{l}0.000 \\
{[0.037]}\end{array}$ & 0.0000 & 0.0000 \\
\hline & IPO & 0.04 & $0.206^{*}$ & 0.043 & 0.141 & 0.042 & 0.2061 & 0.2791 \\
\hline & 311 & {$[0.151]$} & {$[0.111]$} & {$[0.151]$} & [0.096] & [0.067] & & \\
\hline & Non-IPO & $0.542 * * *$ & $0.250 * * *$ & -0.027 & $0.537 * * *$ & -0.021 & 0.0000 & 0.0000 \\
\hline & 574 & {$[0.112]$} & {$[0.080]$} & {$[0.068]$} & {$[0.111]$} & [0.048] & & \\
\hline \multirow{6}{*}{$\begin{array}{l}\text { Technical } \\
\text { efficiency }\end{array}$} & Whole sample & $0.249 * * *$ & 0.051 & -0.004 & $0.286^{* * *}$ & 0.005 & 0.0000 & 0.0001 \\
\hline & 885 & {$[0.090]$} & [0.066] & {$[0.066]$} & {$[0.066]$} & [0.039] & & \\
\hline & IPO & 0.139 & 0.091 & 0.065 & $0.336^{* * *}$ & 0.100 & 0.0146 & 0.0156 \\
\hline & 311 & [0.160] & [0.118] & {$[0.160]$} & [0.102] & {$[0.071]$} & & \\
\hline & Non-IPO & $0.401 * * *$ & $0.205 * *$ & -0.004 & $0.339 * * *$ & -0.032 & 0.0001 & 0.0001 \\
\hline & 574 & {$[0.111]$} & {$[0.080]$} & {$[0.068]$} & {$[0.110]$} & [0.048] & & \\
\hline
\end{tabular}

Notes: Panels A and B of this table present the fixed effect regression for the effects of demutualisation on firm managerial structure and CEO compensation (logistic regressions are performed for "CEO turnover rate"). The key independent variables are the post-demutualisation dummies (which are reported in the table). Constant terms and control variables are not reported (see Section 'Methodology' for a detailed discussion). For "CEO turnover rate" regression, we combine the "Year 0, Year +1 , Year +2 and Year +3" dummies into one "Year 0-3" dummy variable because of the prediction failure of some dummy variables. Panel $\mathrm{C}$ presents the impact of post-demutualisation turnover on firm efficiency. The reported variables are the interaction of post-demutualisation dummies and turnover.

$F$-test (1) tests the hypothesis that the sum of the coefficients of the post-demutualisation dummies (within three years) is equal to 0 ( $P$-value is reported). $F$-test $(2)$ tests the hypothesis that the sum of the coefficients of all the post-demutualisation dummies is equal to zero ( $P$-value is reported). $F$-test $(3)$ and $F$-test $(4)$ are defined similarly.

*significant at the ten per cent level; **significant at the five per cent level; ***significant at the one per cent level. Standard errors in brackets.

Bold indicates at least marginal significance as noted below the table.

non-IPO demutualisation firms, which is also in line with the lack of significant change in performance in these firms.

The $t-1$ CEO exhibits no increase in compensation in non-IPO demutualisation firms, but for IPO demutualisation firms, the $t-1$ CEO's total compensation increases in the first and second year after demutualisation, with no further increase thereafter. This coincides with the performance enhancement of IPO firms after demutualisation and demonstrates that $t-1$ CEOs do not entrench themselves in the converting firms for the long term. They are rewarded, however, and share part of the benefits of performance improvements.

\section{CEO turnover and firm efficiency}

Panel C of Table 6 addresses the effect of post-demutualisation CEO turnover on firm efficiency. The interaction terms of post-demutualisation dummies and turnover dummies are reported. The overall finding is that both IPO demutualisation firms and non-IPO demutualisation firms with turnover experience cost efficiency and technical efficiency gains, Ceteris paribus. 
In summary, demutualisation in the U.S. life insurance industry leads to changes in the internal governance of those firms with structure closer to that of stock firms. ${ }^{65}$ Little evidence of managerial entrenchment after conversion exists, as shown by the higher replacement rate of CEOs after demutualisation. Moreover, these firms benefit from the change of corporate governance, as firms that replace their CEOs experience higher efficiency after conversion.

\section{Conclusion}

We investigate the demutualisation wave in the U.S. life insurance industry during the period of 1993-2003 by analysing 37 demutualisation cases together with their control firms. We broaden the literature on demutualisation by directly examining the relationship between the demutualisation decision and corporate governance by analysing the impact of demutualisation on firm performance, corporate governance structure, and executive compensation, and by utilising frontier efficiency analysis to measure the overall performance of firms.

The paper tests two hypotheses about the motivation of demutualisation: the efficiency hypothesis and the managerial welfare hypothesis. If the firm's efficiency improvement incentives dominate private "managerial" incentives, we expect improvements in efficiency in converting firms and that firm financial characteristics and corporate governance variables will be consistent with the efficiency hypothesis. We also expect little entrenchment of existing management and effective incentive compensation associated with enhanced firm performance. If private managerial incentives dominate the demutualisation decision, we expect efficiency losses, adverse changes in management structure, entrenchment of existing management and an abnormal increase in executive compensation without corresponding improvement in performance.

The analysis shows that firms with a higher proportion of assets in separate accounts and smaller boards are more likely to conduct IPO demutualisation. Firms with lower free cash flow ratios, higher reinsurance ratios, greater geographical diversification, and younger CEOs are more likely to conduct non-IPO demutualisation than matching mutual firms with similar size and premium revenues. Therefore, the ex-ante motivations of demutualisation are more in line with the efficiency hypothesis than with the managerial welfare hypothesis.

The ex post effect of demutualisation shows that demutualisation leads to significant cost efficiency and operating performance improvements for firms conducting IPO demutualisation. For firms that convert but do not issue an IPO, demutualisation is value neutral. In neither case do firms see a reduction in efficiency or performance that would be expected of managers seeking private benefits.

By directly looking at the impact of demutualisation on firm management structure, we find that converting firms experience a sharper decrease in board size and in the proportion of outside board members and a greater increase in the CEO turnover rate than matching mutual firms. Converting firms appear to build effective monitoring systems gradually after conversion, and entrenchment does not occur with

\footnotetext{
${ }^{65}$ Fama and Jensen (1983b), Mayers et al. (1997).
} 
existing CEOs, as shown by the high turnover rate. In addition, firms with postdemutualisation turnover register significant efficiency gains.

Analysis of CEO compensation shows that CEOs of firms that demutualise through an IPO receive higher compensation after the company becomes public, mostly due to incentive compensation, such as stock options. Their higher compensation, together with performance enhancement in such firms, provides support for the efficiency hypothesis. For non-IPO demutualisation firms, we find no increase in CEO compensation, along with no performance improvement.

In contrast to the traditional theory that mutual insurance company managers demutualise to improve their welfare at the expense of the policy-holders through wealth expropriation, ${ }^{66}$ this study finds no evidence of a loss to the policy-holders. We find that demutualisation leads to greater efficiency and operating performance for firms that go public, which potentially leads to higher equity valuation. ${ }^{9}$ The managers share the benefits of higher valuation, as they have publicly traded and valued ownership rights. ${ }^{67}$ In addition, IPO demutualisation increases efficiency at least partially through managerial improvements made possible by operations under a stock charter. This greater efficiency, coupled with greater managerial turnover and an increase in the incentive compensation of CEOs, suggests that the primary motivation for demutualisation is value enhancement rather than managerial private benefits.

\section{References}

Banker, R.D. (1993) 'Maximum likelihood, consistency and data envelopment analysis: A statistical foundation', Management Science 39(10): 1265-1273.

Banker, R.D., Chang, H. and Cooper, W.W. (2004) 'A simulation study of DEA and parametric frontier models in the presence of heteroscedasticity', European Journal of Operational Research 153(3): 624-640.

Banker, R.D. and Natarajan, R. (2008) 'Evaluating contextual variables affecting productivity using Data Envelopment Analysis', Operations Research 56: 48-58.

Berger, A.N., Cummins, J.D., Weiss, M.A. and Zi, H. (2000) 'Conglomeration versus strategic focus: Evidence from the insurance industry', Journal of Financial Intermediation 9(4): 323-362.

Best's Insurance Reports. (2004) Life/Health, United States \& Canada. New Jersey: A.M. Best Company.

Butler, R.J., Cui, Y. and Whitman, A. (2000) 'Insurers' demutualization decisions', Risk Management and Insurance Review 3: 135-154.

Cagle, J.A., Lippert, R.L. and Moore, W.T. (1996) 'Demutualization in the property-liability insurance industry', Journal of Insurance Regulation 14(3): 343-369.

Carow, K.A. (2001) 'The wealth effects of allowing bank entry into the insurance industry', Journal of Risk and Insurance 68(1): 129-150.

\footnotetext{
${ }^{66}$ For example, Mayers and Smith (2004) and Carson et al. (1998).

${ }^{67}$ We collected information on the incentive compensation offered to directors and officers as a group and to $t-1$ CEOs only for IPO demutualisation firms after demutualisation. Not surprisingly, IPO firms use stock and stock options as a compensation mechanism to align the interests of management appropriately. The average stock ownership of management as a group is less than one per cent, with maximum lower than six per cent of the total ownership. The non-zero but relatively low percentage of stock ownership indicates an attempt to align the interests of management with their firms without allowing executives to accumulate enough ownership to become entrenched (Morck et al., 1988). The low percentage stock ownership also suggests that the demutualisation was not designed as a way to transfer significant levels of wealth to current managers through stock compensation. The finding for " $t-1$ " CEOs is similar.
} 
Carson, J.M., Forster, M.D. and McNamara, M.J. (1998) 'Changes in ownership structure: Theory and evidence from life insurer demutualizations', Journal of Insurance Issues 21: 1-22.

Cole, C.R. and McCullough, K.A. (2006) 'A reexamination of the corporate demand for reinsurance', Journal of Risk and Insurance 73(1): 169-192.

Cole, C.S., McNamara, M.J. and Wells, B.P. (1995) 'Demutualization and free cash flow', Journal of Insurance Issues 18: 37-56.

Cooper, W.W., Seiford, L.M. and Tone, K. (2000) Data Envelopment Analysis: A Comprehensive Text with Models, Applications, References and DEA-Solver Software, Norwell, MA: Kluwer Academic Publishers.

Cummins, J.D., Tennyson, S. and Weiss, M.A. (1999) 'Consolidation and efficiency in the U.S. life insurance industry', Journal of Banking and Finance 23(2-4): 325-357.

Cummins, J.D. and Weiss, M.A. (2000) 'Analyzing firm performance in the insurance industry using frontier efficiency and productivity methods', in G. Dionne (ed.) Handbook of Insurance, Norwell, MA: Kluwer Academic Publishers, pp. 767-829.

Cummins, J.D., Weiss, M.A., Xie, X. and Zi, H. (2010) 'Economies of scope in financial services: A DEA efficiency analysis of the U.S. insurance industry', Journal of Banking and Finance 34(7): 1525-1539.

Cummins, J.D. and Xie, X. (2008) 'Mergers and acquisitions in the U.S. property-liability insurance industry: Productivity and efficiency effects', Journal of Banking and Finance 32(1): 30-55.

D'Arcy, S.P. and Gorvett, R.W. (2004) 'The use of dynamic financial analysis to determine whether an optimal growth rate exists for a property-liability insurer', Journal of Risk and Insurance 71(4): 583-615.

Eisenberg, T., Sundgren, S. and Wells, M.T. (1998) 'Larger board size and decreasing firm value in small firms', Journal of Financial Economics 48: 35-54.

Erhemjamts, O. (2005) What drives life insurer demutualizations? working paper, Georgia State University, Atlanta, GA.

Fama, E.H. and Jensen, M.C. (1983a) 'Separation of ownership and control', Journal of Law and Economics 26: 301-325.

Fama, E.H. and Jensen, M.C. (1983b) ‘Agency problems and residual claims', Journal of Law and Economics 26: 327-349.

Fernandes, N., Ferreira, M.A., Matos, P. and Murphy, K.J. (2008) The pay divide: (Why) are U.S. top executives paid more? working paper, University of Southern California, Los Angeles, CA.

Fitzgerald, J.F. (1973) 'Demutualization of mutual property and liability insurers', Journal of Risk and Insurance 40: $575-584$.

Fitzgerald, J.F. (1990) 'Demutualization case studies: A 20-year history', Journal of Insurance Regulation 9: 287-309.

Frech III, H.E. (1980) 'Health insurance: Private, mutuals, or government', in Donald L. Martin (ed.) Economics of Nonproprietary Organization (Research in Law and Economics: Supplement I), Greenwich, CT: JAI Press Inc, pp. 61-73.

Garven, J.R. and Lamm-Tennant, J. (2003) 'The demand for reinsurance: Theory and empirical tests', Insurance and Risk Management 71: 217-238.

Goyal, V.K. and Park, C.W. (2002) 'Board leadership structure and CEO turnover', Journal of Corporate Finance 8: 49-66.

Hadlock, C.J. and Lumer, G.B. (1997) 'Compensation, turnover, and top management incentives: Historical evidence', The Journal of Business 70: 153-187.

Hamilton, L.C. (2003) Statistics with STATA, Version 8. Pacific Grove, CA: Duxbury Press.

Harrington, S.E. and Niehaus, G. (2002) 'Capital structure decisions in the insurance industry: Stocks versus mutuals', Journal of Financial Services Research 21(1): 145-163.

He, E. and Sommer, D.W. (2006) CEO turnover and ownership structure: Evidence from the U.S. property-liability insurance industry, working paper, University of Georgia, Athens, GA.

Ibbotson Associates (2008) Stocks, Bonds, Bills, and Inflation: 2008 Valuation Yearbook, Chicago, IL: Morningstar, Inc.

Jeng, V., Lai, G.C. and McNamara, M.J. (2007) 'Efficiency and demutualization: Evidence from the U.S. life insurance industry in the 1980s and 1990s', Journal of Risk and Insurance 74(3): 683-711.

Jensen, M.C. (1993) 'The modern industry revolution, exit, and the failure of internal control systems', Journal of Finance 48(3): 831-880.

Lai, G.C., McNamara, M.J. and Yu, T. (2008) 'The wealth effect of demutualization: Evidence from the U.S. property-liability and life insurance industries', Journal of Risk and Insurance 75(1): 125-144. 
Lamm-Tennant, J. and Starks, L.T. (1993) 'Stock versus mutual ownership structures: The risk implications', Journal of Business 66(1): 29-46.

Linck, J.S., Netter, J.M. and Yang, T. (2008) 'The determinants of board structure', Journal of Financial Economics 87(2): 308-328.

Lipton, M. and Lorsch, J.W. (1992) 'A modest proposal for improved corporate governance', Business Lawyer 48(1): 59-77.

Mayers, D., Shivdasani, A. and Smith, C.W. (1997) 'Board composition and corporate control: Evidence from the insurance industry', Journal of Business 70(1): 33-62.

Mayers, D. and Smith, C.W. (1981) 'Contractual provisions, organizational structure, and conflict control in insurance markets', Journal of Business 54(3): 407-434.

Mayers, D. and Smith, C.W. (1986) 'Ownership structure and control: The mutualization of stock life insurance companies', Journal of Financial Economics 16(1): 73-98.

Mayers, D. and Smith, C.W. (1988) 'Ownership structure across lines of property-casualty insurance', Journal of Law and Economics 31(2): 351-378.

Mayers, D. and Smith, C.W. (1992) 'Executive compensation in the life insurance industry', Journal of Business 65(1): 51-74.

Mayers, D. and Smith, C.W. (1994) 'Managerial discretion, regulation, and stock insurer ownership structure', Journal of Risk and Insurance 61(4): 638-655.

Mayers, D. and Smith, C.W. (2002) 'Ownership structure and control: Property-casualty insurer conversion to stock charter', Journal of Financial Services Research 21: 117-144.

Mayers, D. and Smith, C.W. (2004) 'Incentives for managing accounting information: Property-liability stock-charter conversions', Journal of Risk and Insurance 71(1-2): 213-251.

McNamara, M.J. and Rhee, S.G. (1992) 'Ownership structure and performance: The demutualization of life insurers', Journal of Risk and Insurance 59: 221-238.

Morck, R., Shleifer, A. and Vishny, R.W. (1988) 'Management ownership and market valuation: An empirical analysis', Journal of Financial Economics 20: 293-315.

Murphy, K.J. and Zimmerman, J.L. (1993) 'Financial performance surrounding CEO turnover', Journal of Accounting and Economics 16(1-3): 273-315.

Pagano, M., Panetta, F. and Zingales, L. (1998) 'Why do companies go public? An empirical analysis', Journal of Finance 53(1): 27-64.

Pottier, S.W. and Sommer, D.W. (1997) 'Agency theory and life insurer ownership structure', Journal of Risk and Insurance 64(3): 529-543.

Remmers, B. (2003) 'Life insurer demutualization in the current era', Journal of Insurance Regulation 22: $75-87$.

Spiller, R. (1972) 'Ownership and performance: Stock and mutual life insurance companies', Journal of Risk and Insurance 34: 17-25.

Viswanathan, K.S. (2006) 'The pricing of insurer demutualization initial public offerings', Journal of Risk and Insurance 73(3): 439-468.

Viswanathan, K.S. and Cummins, J.D. (2003) 'Ownership structure changes in the insurance industry: An analysis of demutualization', Journal of Risk and Insurance 70(3): 401-437.

Weisbach, M.S. (1988) 'Outside directors and CEO turnover', Journal of Financial Economics 20(1-2): 431-460.

Wells, B.P., Cox, L.A. and Gaver, K.M. (1995) 'Free cash flow in the life insurance industry', Journal of Risk and Insurance 62(1): 50-66.

Yermack, D. (1996) 'Higher market valuation of companies with a small board of directors', Journal of Financial Economics 40(2): 185-211.

Yuengert, A.M. (1993) 'The measurement of efficiency in life insurance: Estimates of a mixed normalgamma error model', Journal of Banking \& Finance 17(2-3): 483-496.

\section{About the Authors}

Xiaoying Xie is an Assistant Professor of Finance at California State University, Fullerton. She received her doctoral degree in risk management and insurance from the Wharton School of the University of Pennsylvania. Her research interests include 
mergers and acquisitions, initial public offerings, economies of scale and scope, and corporate governance issues in the insurance industry. She has published articles in peer-reviewed journals such as the Journal of Banking \& Finance, Journal of Risk and Insurance, Managerial Finance and Journal of Financial and Economic Practice.

Weili Lu is a Professor of Finance at California State University, Fullerton. Her current research interests and publications include employee benefits, catastrophic risk pricing, demutualisation, corporate governance and private placement. Dr Lu received her PhD in Finance from the University of Illinois at Urbana-Champaign.

Joseph Reising is an Associate Professor of Finance at Minnesota State Mankato. His current research interests include managerial compensation and regulation of financial institutions. His former positions include Visiting Assistant Professor at the University of California, Irvine and Associate Professor at California State University, Fullerton. $\mathrm{He}$ has published several papers in the areas of compensation and financial institutions. Dr Reising received a PhD in Finance from Texas A\&M University in 1995.

Mark Hoven Stohs is a Professor of Finance and the Chair of the Department, and recent Associate Dean for Academic Programs and Faculty Development in Cal State Fullerton's Mihaylo College of Business and Economics. He received his $\mathrm{PhD}$ in Finance (Economics minor) from the University of Wisconsin, Madison (1994) where he received the EFA Outstanding Doctoral Dissertation Award. He came to Cal State Fullerton in 1996 and was Chair of the department from 2004 to 2006. Dr Stohs has published in the fields of philosophy, real estate, economics and finance. 